\title{
Waste to bioenergy: a review on the recent conversion technologies
}

\author{
Sze Ying Lee ${ }^{1}$, Revathy Sankaran², Kit Wayne Chew ${ }^{3}$, Chung Hong Tan ${ }^{3}$, Rambabu Krishnamoorthy, \\ Dinh-Toi Chu ${ }^{6,7}$ and Pau-Loke Show ${ }^{3^{*}}$ (i)
}

\begin{abstract}
Scientific studies have demonstrated that it is possible to generate a wide variety of bioenergy from biomass residues and waste, and however its cost is not competitive with petro-fuels and other renewable energy. On-going efforts are continued extensively to improve conversion technologies in order to reduce production costs. The present review focuses on the conversion technologies for transforming biomass residues and waste to biofuels, specifically their technological concepts, options and prospects for implementation are addressed. The emerging developments in the two primary conversion pathways, namely the thermochemical (i.e. gasification, liquefaction, and pyrolysis) and biochemical (i.e. anaerobic digestion, alcoholic fermentation and photobiological hydrogen production) conversion techniques, are evaluated. Additionally, transesterification, which appears to be the simplest and most economical route to produce biodiesel in large quantity, is discussed. Lastly, the strategies for direct conversion of biomass residues and waste to bioelectricity including the use of combustion and microbial fuel cells are reviewed.
\end{abstract}

Keywords: Bioenergy, Biofuel, Biomass, biogas, Waste conversion

\section{Introduction}

Since the energy crisis of the 1970s, many countries are interested to develop biomass as a fuel source. Up until recently, the interest in biomass energy has lessened due to the technological breakthrough that makes fossil energy become relatively inexpensive. However, the high greenhouse emissions, deadly air pollution, instable fossil-based energy prices, and strong growth of global transportation fuel demand have boosted extensive research efforts in developing bioenergy. Bioenergy is energy derived from any fuel that is originated from biomass. Biomass is a renewable resource and therefore has been considered as an alternative feedstock to provide sustainable energy in the future. Historically, biomass in the form of firewood has been traditionally used to provide energy to humans through direct combustion.

In industrialized countries, a wide range of feedstocks are available in abundance for biofuel production, including agricultural and forestry residues, building and

\footnotetext{
* Correspondence: PauLoke.Show@nottingham.edu.my;

showpauloke@gmail.com

${ }^{3}$ Department of Chemical and Environmental Engineering, Faculty of Engineering, University of Nottingham Malaysia Campus, 43500 Semenyih, Selangor, Malaysia

Full list of author information is available at the end of the article
}

industrial waste, and municipal solid waste (MSW). The biofuels that are generated from these feedstocks are categorised as second generation biofuels. Differing from first generation biofuels that derived from edible food crops (i.e. sugarcane, wheat, barley, corn, potato, soybean, sunflower, and coconut), second generation biofuels are generated from lignocellulosic materials (i.e. jatropha, cassava, switchgrass, wood, and straw) and biomass residues [1, 2]. The use of biomass residues and waste as primary resource for biofuels is a promising proposal to reduce environmental issues concerning the waste disposal, by converting the wastes that would otherwise have been left to decompose into useful biofuels. Another biomass, namely algae, is introduced as the feedstock for third generation biofuels, owing to their high potential to produce large amounts of lipids suited for biodiesel production. Besides, this fast-growing biomass can be applied directly to generate a wide range of biofuels.

The present review provides an in-depth overview of the technological details of the conversion techniques of biomass residues and waste to biofuels and bioelectricity. More specifically, the review presents a list of the waste-to-energy technological options. Conversion technologies covered in this review include gasification, 
liquefaction, pyrolysis, anaerobic digestion, alcoholic fermentation, photobiological hydrogen production, transesterification, supercritical fluid processing, combustion, and photosynthetic microbial fuel cells (MFC). The review serves to encompass the up-to-date information related to bioenergy production from biomass residues and waste in the rapidly expanding bioenergy field.

\section{Biomass residues and waste}

As opposed to biomass that is specially cultivated for energy purpose, biomass residues and waste are generated along as by-products when the desired raw products are planted, processed and consumed [3]. To be more specific, biomass residues can be categorised into primary, secondary, and tertiary groups. Primary residues typically are generated during the plantation of target food crops and forest products in the field, such as corn stalks, stems, leaves and straw. Whereas, secondary residues are produced when the food crops are processed into final form of products. Woodchips, coffee husk, rice hulls, sugarcane bagasse and palm kernel cake are the examples of agricultural and food processing wastes. Tertiary residues, on the other hand, become available after a biomass-derived product has been consumed by human and/or animals, and these residues might present in the form of MSW [4, 5] and later are further converted to sewage sludge and/or wastewater. Figure 1 illustrates the development of biofuel generation and highlights the second generation biofuels produced by biomass residues and waste, and their conversion pathways to produce different kinds of bioenergy, including syngas, bio-oil, biochar, electricity, biogas, bioethanol, biohydrogen, and biodiesel. Amongst the biomass residues and waste, wood and agricultural residues (primary and secondary biomass residues), waste cooking oils (tertiary biomass residues) and microalgae biomass have demonstrated their promising potentials.

\section{Wood and agricultural residues}

Wood processing wastes like sawdust, wood chips and discarded logs that are generated through sawmill and lumber processing activities can be used as feedstocks for biofuels [6]. For instances, the wood residues and sawdust generated from saw and paper mills industry can be applied as boiler fuels and feedstocks for ethanol production. Besides, Zeng et al. [7] reported that straw has accounted for $72.2 \%$ of the biomass energy resources in China. The straw is referred to the residues or by-products of the harvesting food crops such as rice, wheat, corn, beans, cotton and sugar crops [7]. Corn stover such as stalks, cobs, and leaves, has been also reported to show potential to be converted into fermentable sugars for bio-butanol production [8, 9]. While in tropical countries, sugarcane residues, particularly sugarcane bagasse and leaves, can be a good candidate for the

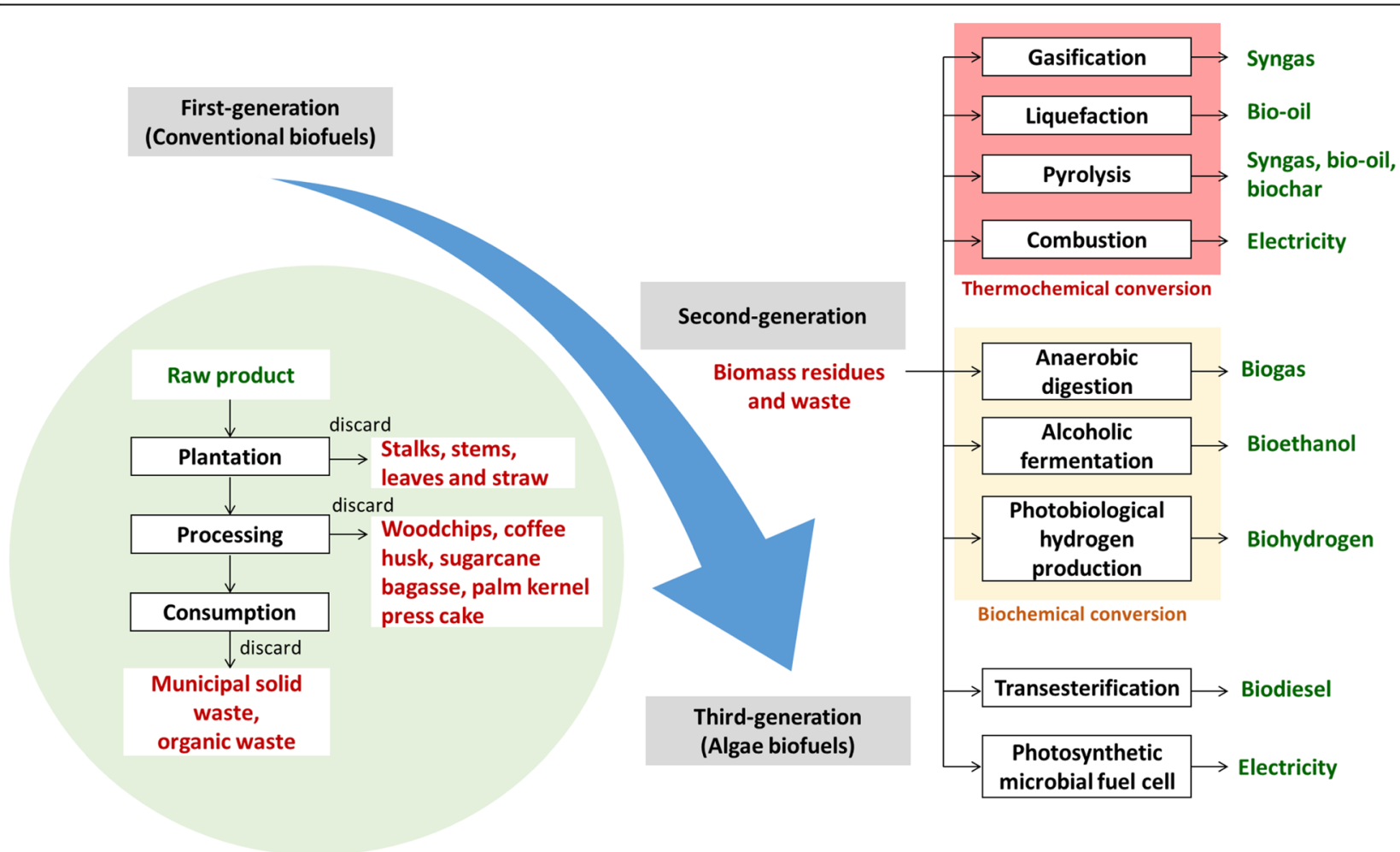

Fig. 1 Diagram of the development of biofuel generation with highlights on the second generation biofuels produced by biomass residues and waste and their conversion pathways to produce a wide variety of bioenergy 
economic utilization of residual substrates for the production of bioethanol $[10,11]$ and other biofuels such as biochar [12]. Palm kernel press cake, a residue obtained from palm oil extraction, demonstrated its use to produce bioethanol via fermentation process $[13,14]$.

\section{Waste cooking oils}

While the high quality food-grade virgin oils are produced from the selected feedstocks, low-cost biodiesel can be derived from waste oils such as used cooking oils $[15,16]$. The use of waste cooking oils instead of virgin oil as feedstocks to produce biodiesel is an efficient method to reduce material cost in biodiesel production [17]. It was reported that the utilization of waste oils is likely to lower the biodiesel production cost by $60-90 \%$ [18]. Additionally, reuse of waste oils alleviates the issues associated with the disposal of large amount of frying oils that are no longer suitable for edible due to the high free fatty acid content [19]. Phan et al. [20] reported that the blend of 20 vol\% the biodiesel produced from waste oils and $80 \mathrm{vol} \%$ diesel (B20) could be applied in engines without major modification. The used edible oils have no significant difference in quality when compared to unused oils, and simple pre-treatments such as filtration and heating can be used to remove water and unwanted solid particles prior to subsequent transesterification [21].

\section{Algae biomass}

In a first approximation, algae can be categorised into two major groups, which are macroalgae (or known as seaweeds) and microalgae. Macroalgae are generally referred to large multi-cellular algae that commonly seen growing in ponds. Whereas, microalgae are unicellular and tiny algae that often grow in a suspension within water-bodies. Macroalgae contain a wide variety of bioactive compounds, and however, lower margins with regard to biofuels can be obtained from macroalgae than microalgae [22]. Therefore, microalgae represent another promising source of oil owing to their high lipids accumulation and fast growth rates. Additionally, microalgae do neither compete for purely agricultural land nor large freshwater resources. Similar to biomass residues and waste, the spent microalgae biomass can be converted to biofuels after the extraction processing of target products such as oils or/and other high value compounds from microalgae biomass.

\section{Bioenergy conversion techniques}

Currently, there is a rise of the impelling need in recycling and energy saving due to present environmental and economic condition. Various diverse technologies were exploited and developed to utilize waste to produce bioenergy. The conversion technology of waste to energy involves the transformation of waste matter into numerous form of fuel that can be utilised to supply energy. In the recent years, environmental-friendly exploitation and conversion of biomass waste into chemical fuels is considered as one of the effective approaches developing renewable energy. There are several technology and process options that are available for biomass energy conversion. Apart from transesterification technique, transformation of waste biomass to energy is carried out using these two general techniques which are thermochemical and biochemical conversion. Conversion by means of thermochemical is the decomposition of organic components in the biomass using heat whereas biochemical conversion utilizes microorganisms or enzymes to convert biomass or waste into useful energy. Conversion by means of thermochemical technology comprises pyrolysis, gasification, liquefaction, and combustion. Biochemical conversion, on the other hand, encompasses three process options known as anaerobic digestion, alcoholic fermentation and photobiological reaction. The following sections review recent studies about the techniques entailed in the conversion of waste to energy systems. Table 1 shows the overview of recent studies that are conducted related to bioenergy conversion using various methods.

\section{Thermochemical conversion}

Conversion through thermochemical technology involves high-temperature chemical reformation process which requires bond breaking and reforming of organic matter into biochar (solid), synthesis gas and highly oxygenated bio-oil (liquid). Within thermochemical conversion, there are three main process alternatives available that are gasification, pyrolysis, and liquefaction. The selection of conversion type can be influenced by the nature and quantity of biomass feedstock, the preferred type of energy, for example; end use conditions, environmental principles, financial circumstances and project precise aspects [59]. Based on several research studies, it was reported that thermal conversion technologies have gained extra attention due to the availability of industrial infrastructure to supply thermochemical transformation equipment that is highly developed, short processing time, reduced water usage and added advantage of producing energy from plastics wastes which cannot be digested by microbial activity [60]. Additionally, thermochemical conversion is essentially independent of environmental circumstances for production purposes. Thus, it is vital to comprehend the different thermochemical process options to assess their future potential.

\section{Gasification}

The gasification technique comprises chemical reaction in an environment which is oxygen-deficient. This process involves biomass heating at extreme temperatures (500$1400^{\circ} \mathrm{C}$ ), from atmospheric pressures up to $33 \mathrm{bar}$ and 


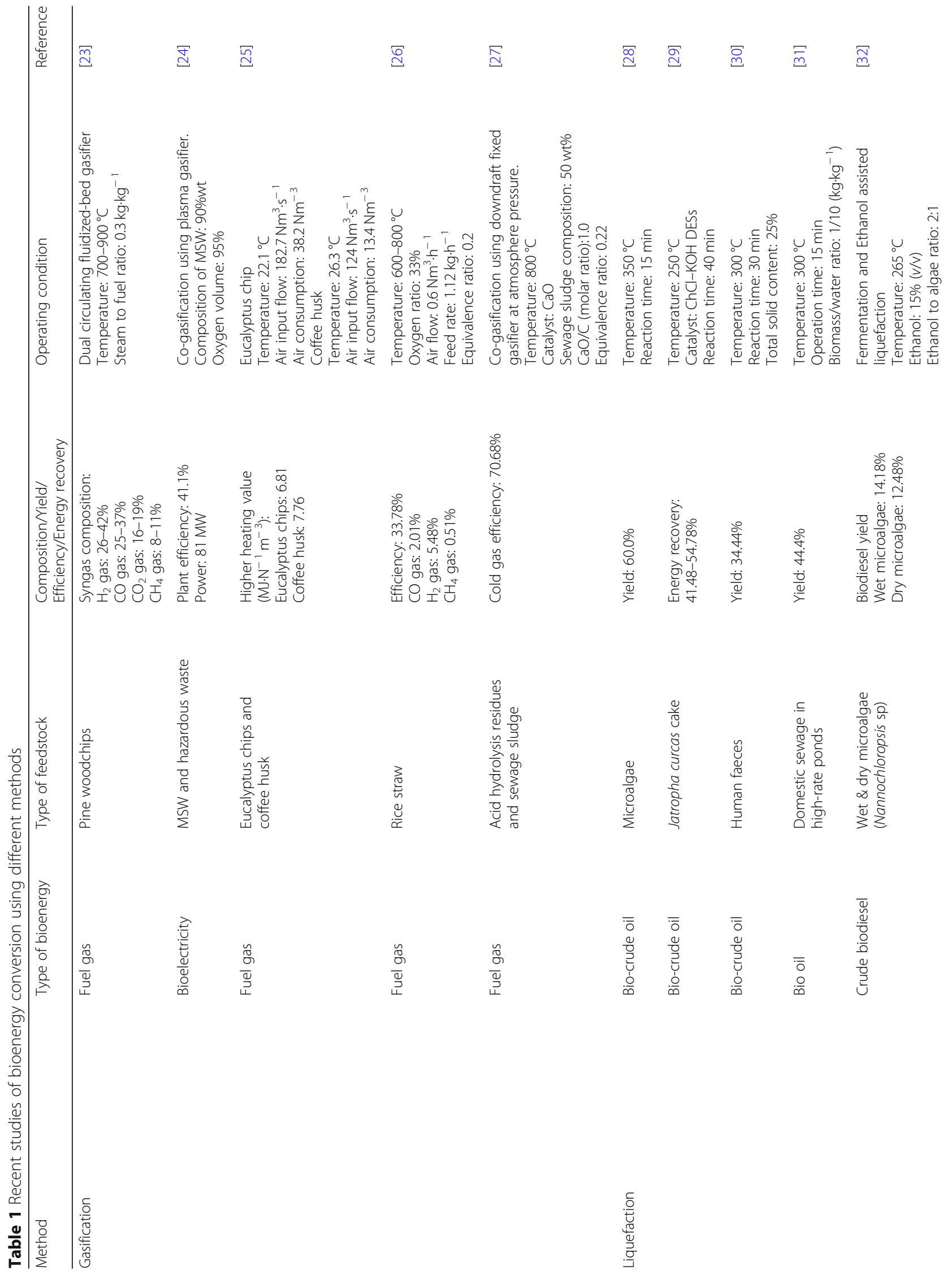


Lee et al. BMC Energy

(2019) 1:4

Page 5 of 22

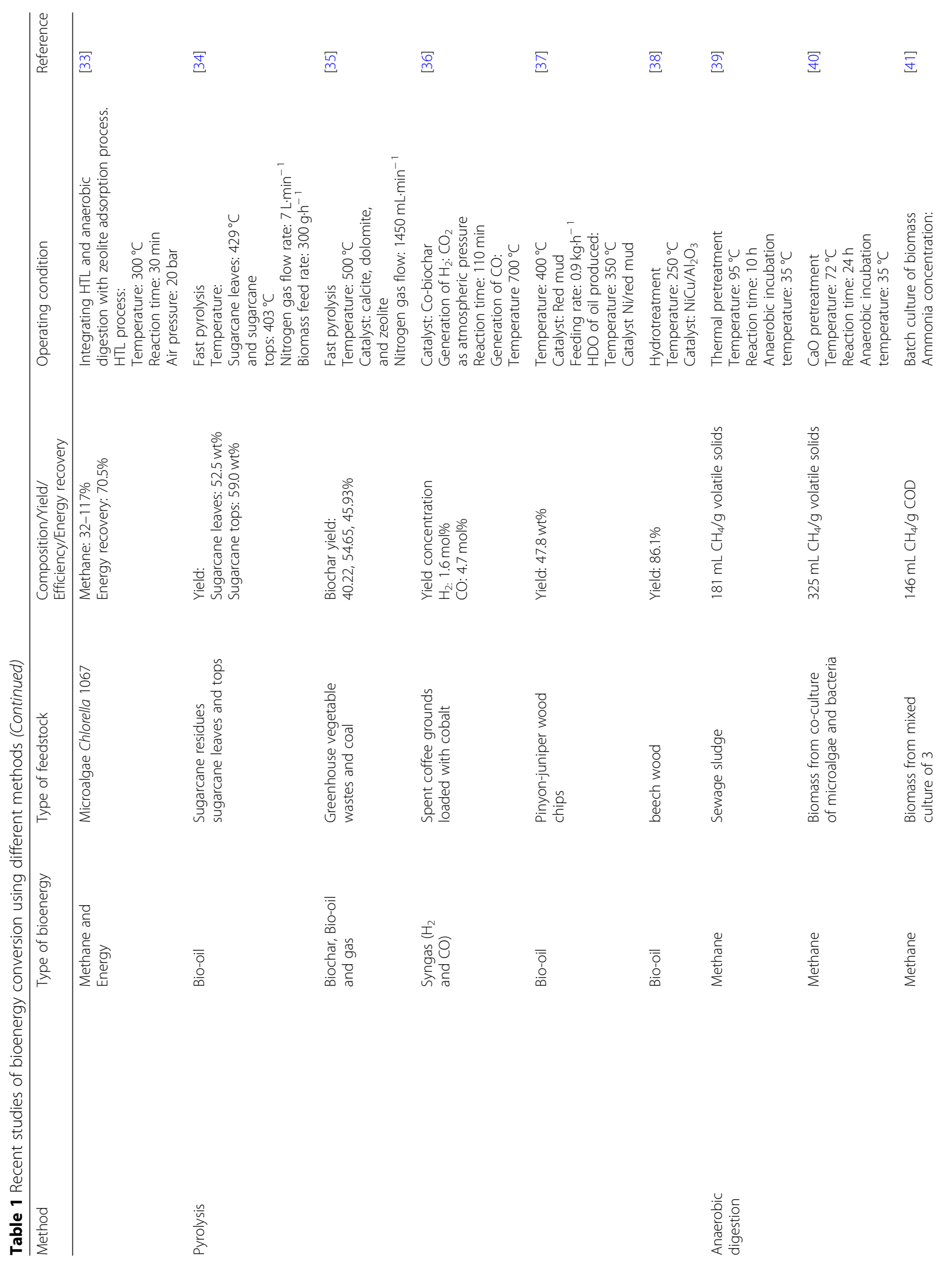




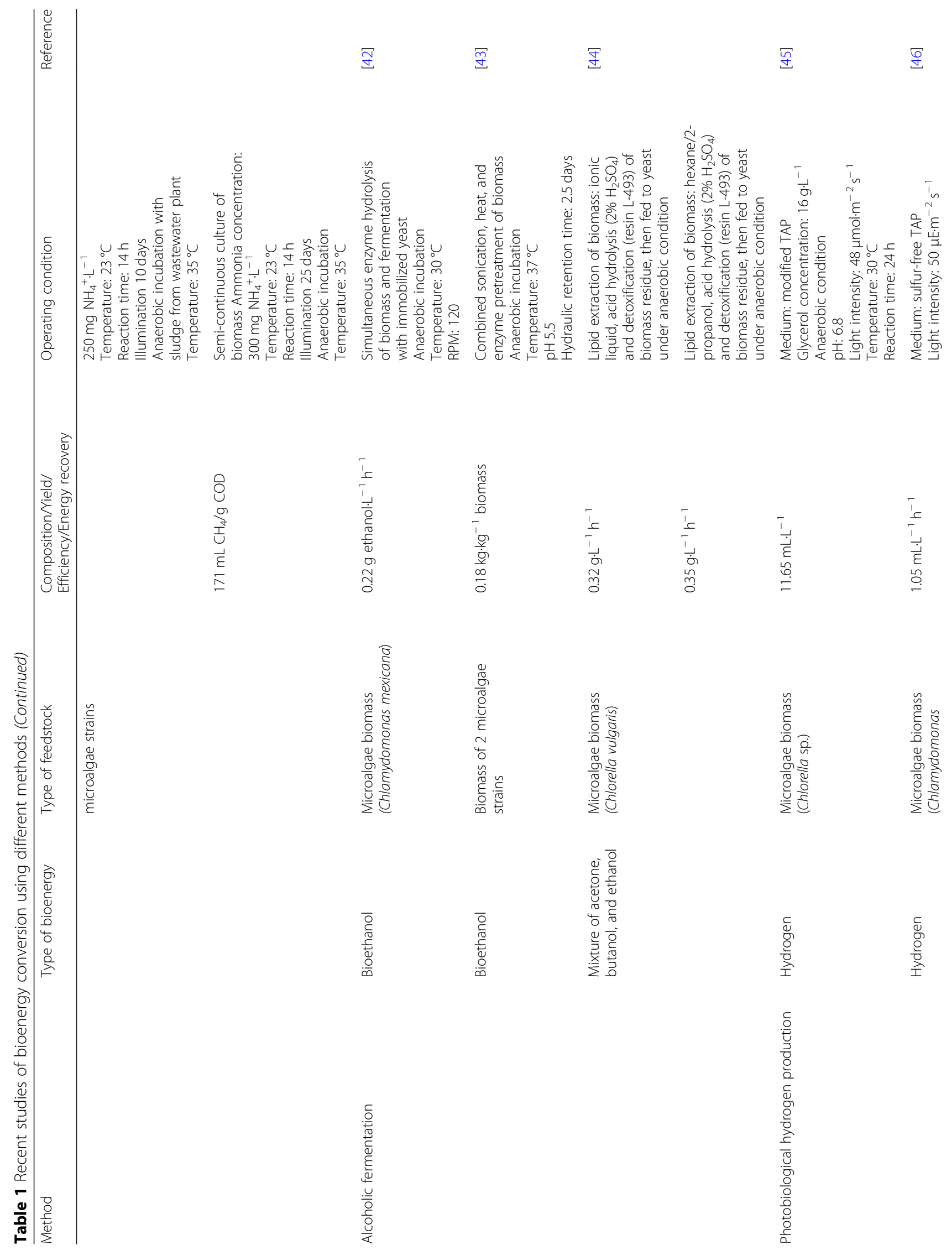


Lee et al. BMC Energy $\quad$ (2019) 1:4

Page 7 of 22

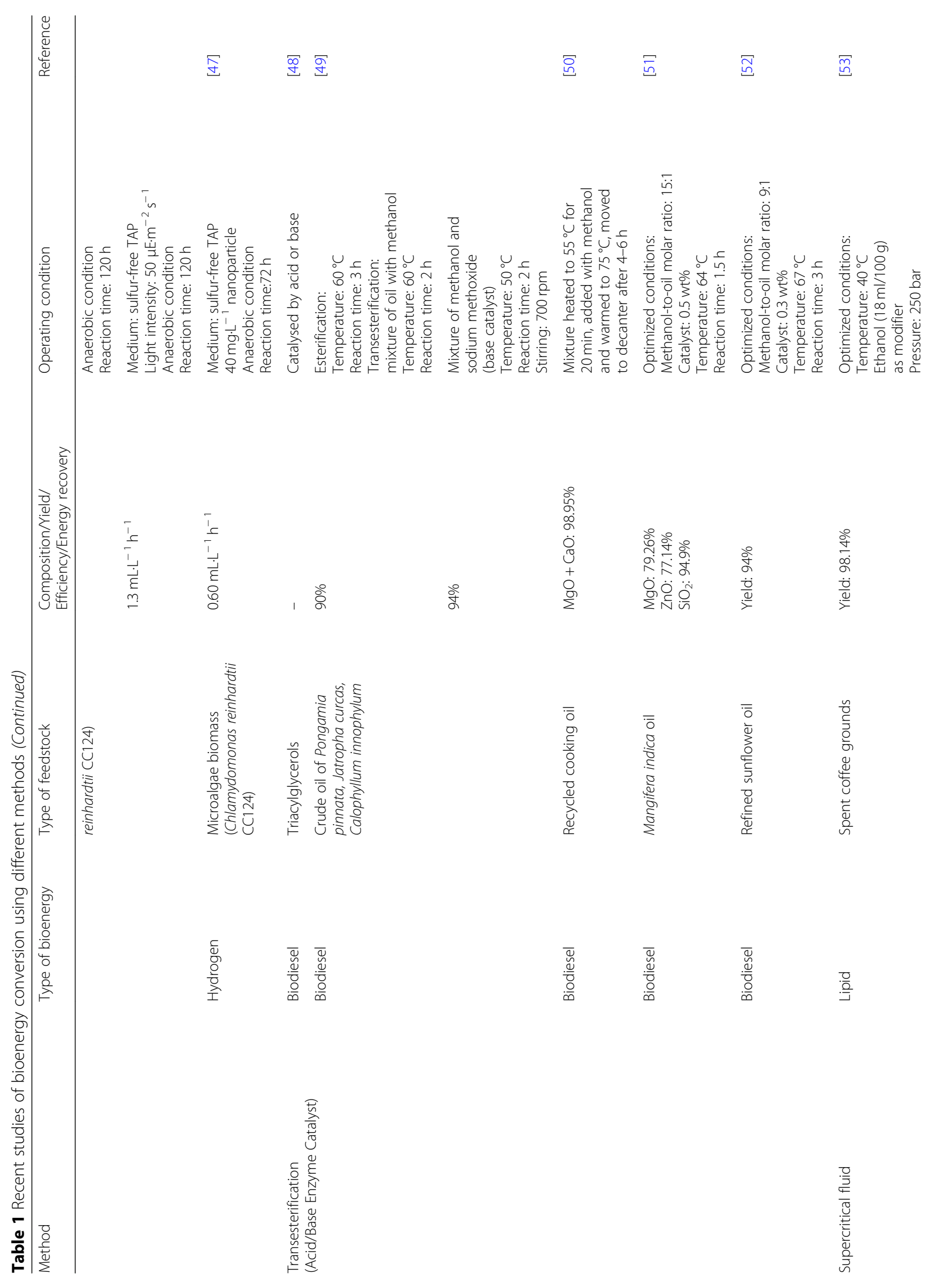


$\begin{array}{ll}\text { Lee et al. BMC Energy } & \text { (2019) 1:4 }\end{array}$

Page 8 of 22

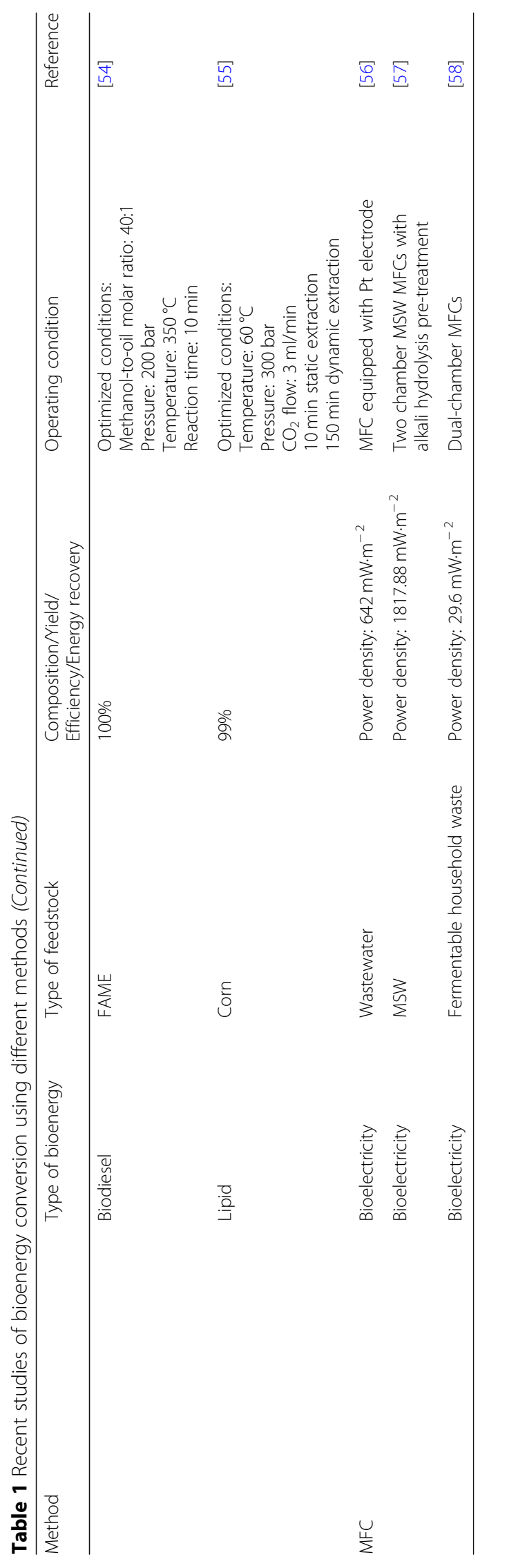


with low/absent oxygen content to yield combustible gas mixtures. Gasification process transforms carbonaceous constituents into syngas comprising hydrogen, carbon monoxide, carbon dioxide, methane, higher hydrocarbons, and nitrogen with the presence of a gasification agent and catalyst. By utilizing this syngas, various types of energy/ energy carriers are supplied for examples biofuel, hydrogen gas, biomethane gas, heat, power and chemicals.

It is reported that gasification process is the most efficient technique in the production of hydrogen gas from biomass [61]. Contrasting to additional thermochemical conversion techniques, gasification technique is considered to be independent autothermic route based on energy balance. It is revealed that biomass gasification able to recover more energy and higher heat capacity compared to combustion and pyrolysis. This is attributed to optimal exploitation of existing biomass feedstock for heat and power production. Conversion of carbon monoxide and hydrogen by means of pyrolysis and liquefaction is poor due to their complexity process, greatly reliant on operating conditions and the presence of secondary reaction resulting from hot solid particles and volatiles [62]. Additional benefit of gasification process is the simple conversion by means of catalytic methanation of carbon monoxide and carbon dioxide of syngas to synthetic natural gas [63]. Thus, gasification of biowaste is deliberated to be ideal route for the conversion of diverse biomass feedstocks varying from wastes of agriculture, industrial, kitchen, food, and farm.

Gas composition produced from gasification process varies according to type of gasifier, gasification agent, catalyst type and size of particle. Generally, high amount of $\mathrm{CO}_{2}$ and $\mathrm{CO}$ is generated via gasification process of feedstock that contains high amount of carbon and oxygen. It is found that among all the waste feedstocks, MSW and agricultural residue have greater $\mathrm{CO}$ and $\mathrm{CO}_{2}$ content [64]. During gasification process, sulphur is emitted as $\mathrm{H}_{2} \mathrm{~S}$ form that causes complexity in gas separation and treatment. That is the reason that gas treatment methods are required for feedstocks that contain high amount of sulphur. Normally, biowaste feedstocks comprise $<1.5 \mathrm{wt} \%$ of sulphur. Among which, sewage sludge and animal waste comprises highest quantity of sulphur with $1 \mathrm{wt} \%$ and $0.5 \mathrm{wt} \%$ correspondingly [64]. Typically, in biowaste gasification, there are four types of gasifier that are used which are fixed bed, fluidized bed, entrained flow, and plasma gasifiers. As for the fixed bed gasifier there are two dissimilar forms known as downdraft gasifier and updraft gasifier. The downdraft gasifier is more popular due to its ability to yield high good quality gas quickly and the utilization of flexible moisture content of the biomass [62]. At present small scale gasifiers are practically utilised for electric power generation and power heat cogeneration [65]. Table 2 outlines the generally employed types of gasification in recent studies for the gasification of biowaste.

Recent study by Salimi and colleague [76] on the energy generation from lignocellulosic wastes of canola stalks discovered the use of novel bimetallic catalysts supported on activated carbon and graphene nano sheets in the hydrothermal gasification process. It was found that the addition of metal such as Nickle (Ni), Rudium

Table 2 Common types of gasifiers investigated in recent studies of gasification of biowaste

\begin{tabular}{|c|c|c|c|c|}
\hline Type of gasifier & Advantages & Type of feedstocks & $\begin{array}{l}\text { Operating } \\
\text { temperature }\left({ }^{\circ} \mathrm{C}\right)\end{array}$ & References \\
\hline \multirow[t]{4}{*}{ Fixed bed gasifier } & \multirow{4}{*}{$\begin{array}{l}\text { - High tolerance of ash content. } \\
\text { - Able to withstand high moisture content feedstock. } \\
\text { - Low tar accumulation. } \\
\text { - Minimum sensitivity towards feedstock size and quantity. }\end{array}$} & Wood & $800-900$ & {$[66]$} \\
\hline & & Sawdust & $650-960$ & {$[67]$} \\
\hline & & Palm shell & 750 & {$[68]$} \\
\hline & & Sewage sludge & 800 & {$[27]$} \\
\hline \multirow[t]{4}{*}{ Fluidized bed gasifier } & \multirow{4}{*}{$\begin{array}{l}\text { - High heat transfer rate. } \\
\text { - Thorough mixing of feedstock and bed material. } \\
\text { - Moderate requirements of gasification medium }\end{array}$} & Pine woodchips & $700-900$ & {$[23]$} \\
\hline & & Beech wood & $750-850$ & [69] \\
\hline & & Rice straw & $600-800$ & {$[26]$} \\
\hline & & Wood and bark waste & $300-400$ & {$[70]$} \\
\hline \multirow[t]{4}{*}{ Entrained flow } & \multirow{4}{*}{$\begin{array}{l}\text { - Flexibility types of feedstock. } \\
\text { - Short processing time. } \\
\text { - Uniformity of temperature throughout reactor. } \\
\text { - Low tar production in gas. }\end{array}$} & Straw biomass & 900 & {$[71]$} \\
\hline & & Jatropha curcas shell & 1000 & {$[72]$} \\
\hline & & $\begin{array}{l}\text { Bituminous coal and } \\
\text { wheat straw }\end{array}$ & 1300 & {$[73]$} \\
\hline & & Empty fruits bunch & 900 & {$[65]$} \\
\hline \multirow[t]{3}{*}{ Plasma } & \multirow{3}{*}{$\begin{array}{l}\text { - Capable to treat both hazardous and non-hazardous wastes. } \\
\text { - Nontoxic method to destroy hazardous waste. } \\
\text { - Easy removal of ash as slag. }\end{array}$} & MSW and plastic solid waste & $1250-1315$ & [74] \\
\hline & & Biomedical waste & 1326 & {$[75]$} \\
\hline & & $\begin{array}{l}\text { Hazardous waste from } \\
\text { oil and gas }\end{array}$ & 1500 & {$[24]$} \\
\hline
\end{tabular}


$(\mathrm{Ru})$, Copper $(\mathrm{Cu})$ and Cobalt $(\mathrm{Co})$ based catalyst able to accelerate the reforming reaction that eventually results in the enhanced hydrogen and methane production. From the study, Ni (20\%)/activated carbon, and Ni (20\%) - $\mathrm{Cu}(2 \%) /$ activated carbon catalysts resulted in greater generation of $\mathrm{H}_{2}, \mathrm{CO}_{2}$ and $\mathrm{CO}$ yields, high catalytic activity and stability [76]. Oliveira et al. [25] studied the feasibility and behaviour of fuel gas produced by the gasification process of coffee waste. The feedstocks were exposed to gasification in an open-source and low-cost downdraft gasifier, via gasifying agent in this case air. From this experiment, the fuel gas produced via eucalyptus chips contributed average higher heating value of $6.81 \pm 0.34 \mathrm{MJ} \cdot \mathrm{Nm}^{-3}$, with pre-dominance of carbon monoxide (20.24 $\pm 0.93 \%)$ [25].

Plasma gasification is a rather novel thermochemical technique that is applicable for harmful biomass wastes. Plasma gasification method is an allothermal method that uses exterior power to heat up and maintain the elevated temperatures. The products that are produced from this process are mostly syngas, slug and ash. Since this process uses high temperature, plasma gasification process able to break down nearly all the materials including medical basis such as bandages, infusion kits, biomedical waste containing cytotoxic drugs, antibiotics and also laboratory waste that comprises biomolecules or organisms that are harmful to be released to the environment [75]. Mazzoni and colleague [74] investigated on plasma co-gasification to evaluate the possibility of plasma gasification in recovering energy from MSW and waste of plastic solid. From the study, they found the process consumes oxygen rich air as plasma forming gas and result in the increase in the plant efficiency beyond $26 \%$. This performance has been recognised as the best point of reference for conventional grounded combustion of waste-to-energy technique [74]. Latest study on plasma gasification of biomedical waste (bonny tissue) and household waste, exhibited that the overall concentration of gas synthesised was 69.6 and 71.1 vol.\%, correspondingly [75].

\section{Liquefaction}

Liquefaction and pyrolysis of biomass are the two techniques that render products as bio-oil or biocrude. Thermochemical liquefaction process involves the production of bio-oil at low temperature and elevated pressure with or without catalyst in the presence of hydrogen. Hydrothermal liquefaction (HTL) or also recognized as hydrous pyrolysis is an established liquefaction type that utilizes subcritical water $(\mathrm{SCW})$ at medium temperatures ranging from 250 to $374{ }^{\circ} \mathrm{C}$ and operating pressure from 40 to 220 bar to convert biomass into bio-oil. HTL process comprises decomposition and repolymerization reactions for bio-oil conversion, aqueous dissolved chemicals, solid deposit and gas. Great pressure in the HTL process aids to maintain water in liquid state, whilst the blending of elevated pressure and temperature leads to the decrease in the dielectric constant and density which influence the hydrocarbons to be water soluble [77].

Generally, HTL method utilizes biomass that contains high moisture that could minimize the cost of drying or dewatering phase. Thus, feedstocks that contain varied content of moisture for instance woody biomass-, wasteand algae-based biomass are suitable for bio-oil production. Based on the US Energy and Agriculture Department research, it was stated that almost 700 million dry tons of biomass feedstocks possibly will be yielded in the US annually and this could contribute for biofuel production. Among resources, forestry and agriculture resources could contribute almost 350 million dry tons [78]. Thus, as they are accessible in vast amount, such bio-generated waste emerges to be worthy applicants for bio-oil production. Woody biomass appears to be suitable feedstock for HTL due to its constituents that mainly comprises of cellulose (30-50\%), hemicellulose (15-35\%) and lignin (20-35\%). Cellulose is a non-polar compound at room temperature however, it is likely to be soluble as the temperature increases and has the advantage of high degree of polymerization. Cellulose has strong intramolecular and intermolecular interactions among hydrogen bonds which is initiated by the glucose monomers [79]. As for hemicellulose, it contains weak arrangement and less resilient hydrogen bonding that causes easy disintegration of the molecules. The yields of bio-oil from woody biomass are influenced by operation parameters, with or without catalyst and type of solvents. From previous studies of woody biomass using HTL, the bio-oil produced varies from 17 to $68 \mathrm{wt} \%$ [77].

In the recent years, there are many research using diverse techniques for HTL process of biomass. Alhassan and colleague [29] utilised deep eutectic solvents (DESs) as a catalyst in the HTL of de-oiled Jatropha cake. DES is used as substitute of ionic liquid catalyst due to its benefits for example straightforward preparation, low degree of toxicity, economical and low temperature stability. In their study, high energy of bio-crude at about (41.48-54.78\%) are recovered by HTL process using de-oiled Jatropha, they able to recover [29]. In another study, Costanzo et al. [80] performed two stage HTL processes consisting of first low temperature followed by high temperature HTL coupled with hydrodenitrogenation and hydrodeoxygenation (HDO) catalyst to extract biocrude from algae. It was discovered that the biocrude produced from this process is comparable to conventional gasoline [80].

Sewage sludge is a derivative of wastewater treatment which encompasses proteins, lipids, fibre, non-fibrous 
carbohydrates, and ash. Sewage sludge is a promising feedstock for HTL process as it readily available in large volumes. In addition, it is reported that compared to dry sludge, exploiting wet sludge able to decrease the consumption of energy by $30 \%$ [81]. The challenge in the production of quality bio-oil using dewatered sewage sludge is the high moisture content which is higher than $85 \%$ [82]. There are several studies conducted in the attempt to reduce the moisture content in sludge which include the use of dry straw [83], co-liquefaction [84], $\mathrm{n}$-hexane to isolate bound water [85], methanol for extraction of extracellular polymeric substances [86] and SCW pre-treatment to break up sludge cells resulting the relief of bound and surface water [87]. In a latest study by Yang and colleague [88], the effects of co-pre-treatment of cationic surfactant-non-ionic surfactant (fatty alcohol polyoxyethylene ether $\mathrm{AEO}_{9}$ )SCW on the HTL of sludge for bio-oil production are studied [88]. From this study, high amount of bound water is able to be released from the sludge that consequently caused high production of bio-oil (up to 47.6\%). The utilization of co-pre-treatment of cationic surfactant-fatty alcohol polyoxyethylene ether $\mathrm{AEO}_{9}-\mathrm{SCW}$ lead to improvement of the hydrocarbons in the bio-oil and amplified its calorific value by $15.5 \%$.

It is revealed that during HTL process, not all the organics present in the feedstocks are converted to bio-oil. There are remaining organics left in the liquid as post-hydrothermal liquefaction wastewater (PHWW) which is known to have numerous significant nutrients [89]. Researchers learned that approximately $20 \%$ of the carbon from the feedstock is transferred into PHWW. The carbon transferred will be mostly in the form of monosaccharides, oligosaccharides and organic acids such as acetic acids $[28,30]$. Thus, it is vital to improve the technology that able to recover the remaining organic carbons from PHWW and transform them into products with high value. This will definitely support the overall cost-effective viability and economic possibility of HTL. Recently, Li's research group [33] introduced an integration process of HTL and anaerobic digestion to advance methane production and energy recovery of PHWW from Chlorella. Energy recovery from PHWW was conducted by using zeolite adsorption and anaerobic digestion. From this study, it was demonstrated that the addition of zeolite and the integration system increased the efficiency of energy recovery to $70.5 \%$.

Lately there are immense amount of work concerning to HTL using wet microalgae due to its advantages of eliminating drying process and the lipid, protein and carbohydrate fractions conversion into bio-oil liquid with or without catalyst [90]. In a current study, Rahman et al. [32] introduced a green biorefinery concept of merging fermentation and ethanol aided liquefaction to yield biofuels from marine microalga Nannochloropsis sp. This study showed that pre-treatment and fermentation of wet microalgae improved the total lipid production by 40 and $10 \%$ of essential solvent for succeeding phase of biofuel production. The integration of algae to liquid process increases the yield of biodiesel by three-fold contrasting to liquefaction of microalgae.

\section{Pyrolysis}

Amongst the thermochemical biomass conversion routes, pyrolysis and gasification are the two processes that are commonly being studied. Pyrolysis is thermal decomposition of biomass that takes place in the absenteeism of oxygen with operating temperature ranges from 350 to $550^{\circ} \mathrm{C}$ that could reach up to $700^{\circ} \mathrm{C}$. Pyrolysis process decomposes organic materials into solid, liquid and gas mixture. The difference between gasification and pyrolysis is that gasification produces fuel gas that is able to be combusted for heat generation. Whereas, pyrolysis process produces liquid fuel known as pyrolysis oil (py-oil)/ bio-oil that can be an alternative for fuel oil in the application of static heating or in the generation of electricity. The advantage of liquid fuel that is being produced by pyrolysis over fuel gas of gasification process is that the yielded bio-oil can be straightforwardly stored and effortlessly be transported [91]. There are three types of pyrolysis process (as shown in Fig. 2) that differ according to their operation conditions, namely slow, fast and flash pyrolysis. Their products composition is influenced by the operating conditions. Slow pyrolysis involves decomposition process that produces char at low temperature, heating rate and long vapour residence time. The key outcome of fast pyrolysis is bio-oil that occurs at controlled temperature approximately $500^{\circ} \mathrm{C}$, short residence time $(<2 \mathrm{~s})$ and high heating rate $\left(>200^{\circ} \mathrm{C} \cdot \mathrm{s}^{-1}\right)$. While for flash pyrolysis, the reaction time is extremely short and the heating rate is higher than fast pyrolysis.

Currently, more attention is given on the liquid production from fast pyrolysis. This is due to the advantages of the high yield of py-oil up to $75 \mathrm{wt} . \%$ and the technology that is cost effective, highly efficient in energy and environmentally friendly [92, 93]. Py-oil exists as dark brown, with high viscosity. It uses low calorific value and it is comprised of several chemical compositions that include acids, alcohols, aldehydes, phenols and oligomers that are originated from lignin [94]. In the recent years, improvements of py-oil properties become major concern. The enhancement of py-oil is required so that it could be utilised as a substitute to crude oil. There are several routes for the py-oil upgrading that include physical, chemical and catalytical approaches.

Physical upgradation In physical upgradation, hot vapour filtration is the most frequent method being used 


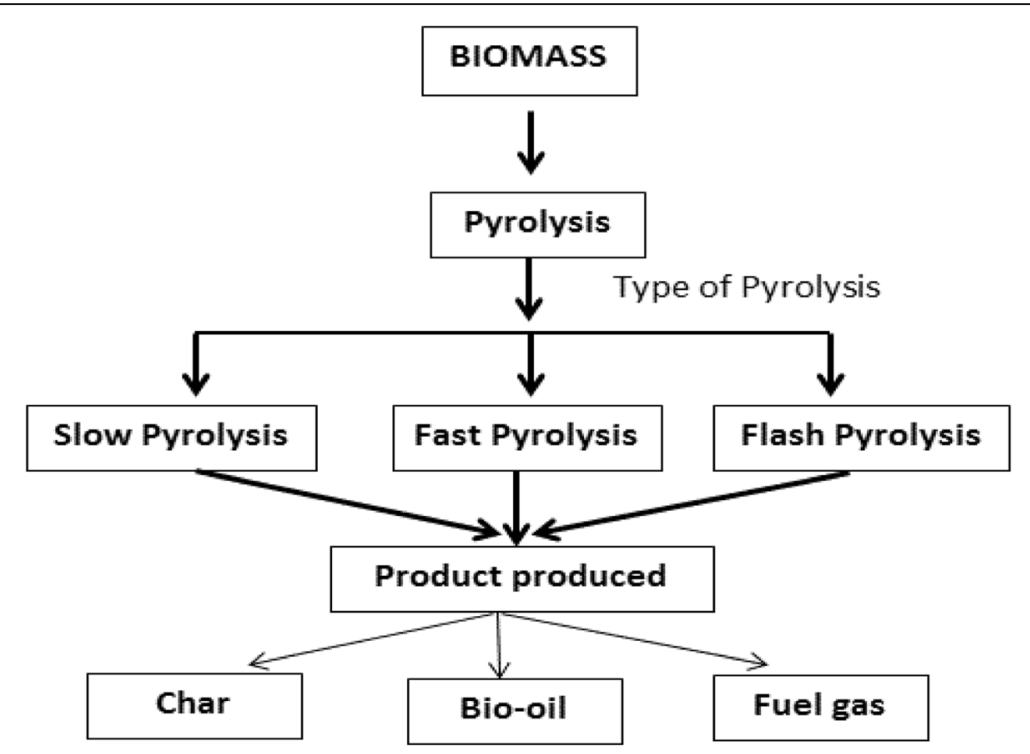

Fig. 2 Illustration of different types of pyrolysis process

to get better bio-oil. It enables to reduce the initial molecular weight of the oil and slows down the rate of bio-oil aging. Case and colleagues [95] analysed the chemical and physical variations of bio-oil of pine sawdust pyrolysis using various hot gas filtration conditions. From the study, they found significant improvement on the oil stability. The application of hot gas filtration causes the elimination of char and inorganic materials from the oil which is initiated due to the removal of the highly unstable compound of ring- conjugated olefinic substituents and the conversion of guaiacol-type compounds to catechol- and phenol-type compounds [95]. Pattiya and Suttibak [34] used hot filter on the fluidised bed reactor pyrolysis of sugarcane leaves and tops. It was observed that though the bio-oil yield was reduced by $7-8 \mathrm{wt} \%$, the filtered bio-oils have improved viscosity and stability [34]. In a recent study of hot gas filtration, Ruiz group [96] introduced hot gas filtration (HGF) unit (in situ) in a typical pyrolysis. They studied on the influence of in situ filtration on bio-oil yield and chemical composition of bio-oil. It was discovered that secondary reactions inside the HGF unit influences the yield which was controlled by HGF temperature, HGF char cake thickness and alkali and alkaline earth metallic content of the raw feedstock [96].

Hydrodeoxygenation upgradation HDO or also known as hydrotreatment is another strategy that offer enhanced oil yield, high oil quality and with higher carbon recovery. This process involves the removal of oxygen from oxygenated hydrocarbons via catalytic reaction at high pressure (up to $200 \mathrm{bar}$ ), hydrogen supply and moderate temperature (up to $400{ }^{\circ} \mathrm{C}$ ) [92]. It is stated that HDO process able to improve the py-oil quality by refining oil stability and increases energy density [97]. There are four main reactions that affect the HDO of py-oil which are (i) hydrogenation of $\mathrm{C}-\mathrm{O}, \mathrm{C}=\mathrm{O}$ and $\mathrm{C}=\mathrm{C}$ bonds, (ii) dehydration of $\mathrm{C}-\mathrm{OH}$ group, (iii) condensation and decarbonylation of $\mathrm{C}-\mathrm{C}$ bond cleavage using retro-aldol and (iv) hydrogenolysis of $\mathrm{C}-\mathrm{O}-\mathrm{C}$ bonds [98-100]. The main challenge in HDO of py-oil is the deactivation of catalyst and there is a necessity to synthesis effective catalyst for HDO process.

In the effort to upgrade pyrolytic oils, numerous catalyst that include non-noble and noble metal catalysts were studied. Newly, Jahromi and Agblevor [37] synthesised a novel multifunctional red mud-supported nickel $(\mathrm{Ni} / \mathrm{red} \mathrm{mud})$ catalyst and associated their performance with commercial $\mathrm{Ni} / \mathrm{SiO}_{2}-\mathrm{Al}_{2} \mathrm{O}_{3}$ for the $\mathrm{HDO}$ of aqueous-phase pinyon-juniper biomass chips. Based on this study, it was discovered that the usage of newly synthesised Ni catalyst produced liquid hydrocarbon due to the cross-reactions of HDO intermediates on the Ni/red mud while the commercial catalyst did not produce any. A new study on the HDO of py-oil produced from the integration of intermediate pyrolysis and hot gas filtration of beech wood showed that bio-oil with improved quality was produced. It was found that the type of catalyst and the choice of the HDO temperature play a major role in the conversion and product composition [38]. In several studies, it was found that the use of $\mathrm{Pd} /$ $\mathrm{C}$ as a catalyst is promising approach in contributing great oil production and high level of oxygen elimination for hydrotreating the py-oil $[101,102]$. In a latest attempt of using $\mathrm{Pd} / \mathrm{C}$ catalyst, Wang and Lee [103] investigated two sorts of researches, fluidized bed fast 
pyrolysis of Miscanthus and HDO of the bio-oil. Based on the result obtained, oil was successfully upgraded into a great substitute of transportation fuel [103].

Catalytic upgradation Another alternative method in upgrading py-oil is the use of catalysts. There are two methods involve in the enhancement of pyrolysis oil quality. The first comprises in the downstream process by means of metallic or bi-functional (hydrogenating and acidic) catalysts and the other is in-situ upgradation by integrated catalytic pyrolysis [91]. In the catalytic process, the vapour that is produced by pyrolysis will go through extra cracking within the catalyst pore for the formation of low molecular weight compound. In the py-oil, the undesired products which cause the increase in the oil acidity and viscosity are carboxylic and carbonyl groups. During pyrolysis process, the catalysts with the capability in altering the organic acids into alcohols, for an example zeolitic catalysts, are widely used in oil refineries. This is because of their capability to break long chain and promote formation of aromatic hydrocarbons.

In most zeolite catalytic study, the size of micropore/ mesopore is needed to be taken into consideration to ensure the entry of huge biomass chains into zeolite pores to increase yield of hydrocarbons [104]. The conversion of pyrolysis vapours via acid-catalysed reactions leads to the breaking of $\mathrm{C}-\mathrm{O}$ and $\mathrm{C}-\mathrm{C}$ bonds among guaiacyl, syringyl and p-hydroxylphenyl and produces intermediates that cause for the coke formation on the zeolite surface [94]. In a recent investigation by Hoff and colleague [105], the mesoporosity of the zeolite is increased by using rich-ZSM5 obtained through desilication. The enhanced mesoporosity directed to the increase in the aromatic yields during the red oak pyrolysis [105]. The in-situ mode of reaction is desired most for py-oil because it can be accomplished using at various operating temperatures and catalyst loading ratios [94].

\section{Biochemical conversion}

Biochemical conversion encompasses the utilization of the yeast and/or specialized bacteria yeast to convert biomass or waste into useful energy. The classical process options are anaerobic digestion, alcoholic fermentation and photobiological techniques which lead to different biofuels produced.

\section{Anaerobic digestion}

As microalgae biomass contain high amounts of nutrients (such as carbohydrates, proteins, and lipids), full utilization of the biomass will improve the economic, sustainability and green aspects of microalgae biorefineries [106]. One way to maximize nutrient extraction is via anaerobic digestion of the biomass residue obtained from biodiesel synthesis process. In anaerobic digestion, the spent microalgae biomass is converted into biogas by microorganisms, and the biogas contains mainly $\mathrm{CH}_{4}$ and $\mathrm{CO}_{2}$ with trace quantities of $\mathrm{H}_{2} \mathrm{~S}$. The biogas has an energy content of $20-40 \%$ of the biomass lower heating value. Anaerobic digestion can accommodate wet biomass with moisture content up to 90\% [107]. There are three major phases in anaerobic digestion, namely hydrolysis, fermentation, and methanogenesis. Hydrolysis breaks down complicated biomolecules in the biomass into simple biomolecules, and fermentation uses the simple biomolecules to construct alcohols, acetic acid, fatty acids that are volatile, and $\mathrm{H}_{2}$ and $\mathrm{CO}_{2}$ gas mixture. Methanogens metabolized this gas mixture producing biogas comprising $\mathrm{CH}_{4}(60-70 \%)$ and $\mathrm{CO}_{2}(30-40 \%)$ [108].

Apart from the main nutrients found in microalgae biomass (carbon, nitrogen, and phosphorus), trace elements (such as iron, zinc, and cobalt) present in the biomass have also been observed to encourage methanogenesis [109]. If there is prior knowledge of the content of organic compounds present in the microalgae biomass, the theoretical $\mathrm{CH}_{4}$ and $\mathrm{NH}_{3}$ production from anaerobic digestion can be estimated. Greater lipid content will induce higher yields of methane, although the rate of hydrolysis is slower in lipids compared to carbohydrate and proteins. The minimum duration for adequate hydrolysis of biocompounds for anaerobic digestion was calculated to be $0.18,0.43$, and 3.2 days for carbohydrates, proteins, and lipids respectively [110].

The parameters affecting the yield and energy content of biogas include nutrient profile of biomass, operating temperature, operating $\mathrm{pH}$, biomass loading rate, as well as hydraulic and solid retention time. The hydraulic and solid retention time must be optimized so that the hydrolysis process (rate-determining step) is not limited by slow loading rates and the methanogenesis process is not bounded by rapid loading rates [106]. The hydrolysis process is rate-limiting due to the difficulty in hydrolyzing microalgae cell walls. Therefore, the loading rates and retention time are strongly affected by the selected microalgae species. In the methanogenesis phase, the operating $\mathrm{pH}$ plays an important role in increasing the ratio of $\mathrm{CH}_{4}$ in the biogas. As fermentation proceeds, $\mathrm{NH}_{3}$ concentration (nitrogen waste secreted by the microbial communities) increases causing $\mathrm{pH}$ to also increase. The higher $\mathrm{pH}$ results in the dissolution of $\mathrm{CO}_{2}$ in the fermentation broth, and this enhances the $\mathrm{CH}_{4}$ concentration in the biogas. Higher $\mathrm{CH}_{4}$ content is desirable as it results in greater energy content of the biogas. Apart from $\mathrm{pH}$, higher operating temperature also encourages microbial activity and $\mathrm{CH}_{4}$ production. For instance, raising the temperature from 15 to $52^{\circ} \mathrm{C}$ using Spirulina maxima biomass improved $\mathrm{CH}_{4}$ productivity and volatile solids reduction by $35 \%$ [111]. 
One main challenge facing anaerobic digestion is the low concentration of biomass in the feed stream. A study concluded that a concentrating step for microalgae biomass was essential for optimum operation of the anaerobic digester. When the biomass feed stream was too diluted, the microbial communities were washed out due to lack of digestible nutrients. Another issue is the recalcitrant nature of microalgae cell walls which delays the hydrolysis process. To tackle this, cell disruption can be carried out on the microalgae biomass to break down the cell walls. This way, the nutrients inside the microalgae cells will become available for hydrolysis and subsequent uptake by the microbial communities. The greater the availability of short-chain nutrients, the higher the $\mathrm{CH}_{4}$ yields in the biogas. Cell disruption methods are broadly divided into three categories, namely physical (e.g. microwave, ultrasonication, and bead milling), chemical (e.g. acid/alkali treatment), and enzymatic methods [112]. The low carbon to nitrogen $(\mathrm{C} / \mathrm{N})$ ratio of microalgae biomass (from 4.16-7.82) also presents an issue for anaerobic digestion. If the $\mathrm{C} / \mathrm{N}$ ratio is less than 20 , a nutrient imbalance occurs in the anaerobic microbial community and causes the release of $\mathrm{NH}_{3}$ as nitrogen waste. High concentrations of $\mathrm{NH}_{3}$ can inhibit the methanogens and promote the accumulation of volatile fatty acids in the digester [106]. The low $\mathrm{C} / \mathrm{N}$ ratio can be remedied by co-digesting microalgae biomass with other waste streams such as pig manure [113], cow manure [114], and paper waste [115].

\section{Alcoholic fermentation}

Bioethanol can be obtained via alcoholic fermentation of biomass residues containing fermentable sugars that are converted from cellulose and hemicellulose components of biomass in the existence of yeast or bacteria. For an example, microalgae species for instance Chlorella, Chlamydomonas, Scenedesmus, Dunaliella, and Spirulina have been reported to collect large amounts of starch, glycogen, and cellulose (more than 50\%dw.). These complex polysaccharides are the raw materials needed for bioethanol production. As the microbes have difficulty metabolizing the polysaccharides, hydrolysis is carried out to break down the polysaccharides into simple sugars before feeding. The most common hydrolysis methods utilize acid/alkali and enzymes. Acid treatment is cheap and fast, but the acidic environment may alter the sugars into undesirable forms. In contrast, enzymatic treatment is efficient and does not yield undesirable by-products, but enzymes are expensive and slower. Cell disruption methods can be performed before hydrolysis to increase the efficacy and shorten the duration of hydrolysis [112]. The crude alcohol (10-15\% ethanol) produced must undergo a concentration step using distillation [116]. The remaining solid residue can still be processed into valuable products using liquefaction, gasification, or microwave-assisted pyrolysis.

Genetic engineering of microalgae strains has been researched to enhance yields of valuable metabolites or switch to the production of a different metabolite. One of the aims of genetic engineering is the direct translation of $\mathrm{CO}_{2}$ to biofuels using photosynthesis, as this pathway would not expend energy toward the assembling and break down of biomolecules needed for energy storage and cell structures. During photosynthesis, glucose and other metabolites are synthesized via the Calvin cycle, where ribulose-1,5-bisphosphate reacts with $\mathrm{CO}_{2}$ yielding two 3-phosphoglyceric acid which are precursors to the assembly of glucose [117]. Studies have been performed to redirect the 3-phosphoglyceric acid molecules to assemble ethanol instead by inserting genes responsible for ethanol synthesis (pyruvate decarboxylase and alcohol dehydrogenase). In one study, a proteobacteria Rhodobacter sp. was successfully engineered into an ethanogenic recombinant strain. The recombinant strain was an anaerobe, generating ethanol in the company of light and absenteeism of oxygen.

\section{Photobiological hydrogen production}

Some biomass such as microalgae have the natural ability to produce $\mathrm{H}_{2}$ gas in the presence of light. In photosynthesis, microalgae transform water molecules into $\mathrm{O}_{2}$ and $\mathrm{H}^{+}$. Hydrogenase enzymes then reduce the $\mathrm{H}^{+}$into $\mathrm{H}_{2}$ gas under anaerobic conditions. The $\mathrm{O}_{2}$ released during photosynthesis rapidly inhibits the hydrogenase enzymes and interrupts the release of $\mathrm{H}_{2}$ gas. This implies that anaerobic condition is necessary for the culturing microalgae for the $\mathrm{H}_{2}$ gas production [108]. There are two key methods to extract photosynthetic $\mathrm{H}_{2}$ using microalgae. First approach is the simultaneous production of $\mathrm{O}_{2}$ and $\mathrm{H}_{2}$ gas in the presence of light. The electrons generated from oxidation of water molecules are used by hydrogenase enzymes to yield $\mathrm{H}_{2}$ gas. Theoretically, this method has higher yields than the second approach, but the $\mathrm{H}_{2}$ production is rapidly inhibited by the $\mathrm{O}_{2}$ production [118]. The second approach is to utilize a two-phase system, where the first phase is culturing microalgae under normal conditions and the second phase is promoting continuous $\mathrm{H}_{2}$ generation under anaerobic and sulfur-deprived conditions [118]. Sulfur deprivation engages the microalgae in a survival state where the energy required by the cells are obtained through the release of $\mathrm{H}_{2}$. In the two-phase system, the $\mathrm{H}_{2}$ production would begin to decline after $60 \mathrm{~h}$ of operation, and the theoretical maximum $\mathrm{H}_{2}$ yield could reach $198 \mathrm{~kg} \mathrm{H}_{2}$ ha $^{-1}$ day $^{-1}$ [119].

The duration of $\mathrm{H}_{2}$ production in sulfur-deprived cultures could be lengthened via addition of small quantities of sulfur. After sulfur addition, the condition of 
microalgae cells was improved and their PSII systems were temporarily activated without the presence of an aerobic environment [120]. Regular sulfur addition of five intervals over a period of one month permitted the reconstitution of the cells and enhanced the total $\mathrm{H}_{2}$ yield by 3-4 times compared to the control culture with no sulfur addition [121]. Nonstop systems for $\mathrm{H}_{2}$ generation have been tested, where a two-stage chemostat bioreactor was employed. Microalgae culture in the chemostat were constantly fed with new cells and small quantities of sulfur, and $\mathrm{H}_{2}$ production persisted for five and a half months. Another method to prolong microalgae $\mathrm{H}_{2}$ production is immobilizing the cells on a solid surface during culturing. Immobilization on glass has been done to enable $\mathrm{H}_{2}$ generation for 90 days [122], while immobilization on alginate matrix has increased the specific $\mathrm{H}_{2}$ productivity and $\mathrm{O}_{2}$ resistance of the cells compared to the control (non-immobilized) culture.

\section{Transesterification}

The use of potential biomass such as cellulosic biomass for biofuel production is more complex as the properties and performance of the extracted oil needs to be tuned to suit the properties of hydrocarbon-based fuels. The challenge lies in the conversion of the oil and fats obtained from these biomasses into suitable biofuels in order to be effectively used as a substitute to the conventional fuel. Biofuels obtained from biomass such as lignocellulosic materials often have the issue of high viscosity, low vitality and polyunsaturated characteristics. These issues can be resolve through several pretreatment methods where the most viable method is transesterification. Transesterification is the reaction where fats and oils are converted to form esters and glycerol in the presence of catalysts. The physical characteristics of the fatty acid methyl ester (FAME) produced would then be comparable with the commercial petroleum fuel and the by-product glycerol also has commercial value.

\section{Acid/base and enzyme catalysis}

Generally, there are three groups of catalysts exploited for biodiesel production, namely acid, base and enzymes. Base-catalyzed transesterification is frequently applied for commercial production as it gives higher FAME yield rapidly with mild reaction conditions contrasting to acid-catalyzed transesterification. On the other hand, enzyme catalysts are more environmental friendly and can produce high quality products, but its slow reaction rate and high cost needs further development to make it more feasible.

Biodiesel are commonly produced by using a two-step esterification-transesterification procedure. In the production of biodiesel which are suitable for common internal combustion engines, the lipid granules content would need to be changed into a lesser viscosity type. This is usually done through the transesterification of triacylglycerols to produce fatty acid alkyl esters. The transesterification catalyst may be a lipase or a chemical such as an acid or base. Due to the high energy consumption, large volumes of salt and water needed and the requirements for the conventional transesterification process, the development of an enzymatic transesterification, catalysed by intracellular or extracellular lipases, have been recommended [48]. Many strategies which include protein engineering, enzyme immobilization and whole cell catalyst can be used to improve the enzyme catalyst performance. Enzyme catalyst are able to work in gentler environment, with lower energy consumption and can reduce the need for separation step after transesterification. Enzyme catalysts are able to prevent saponification and require only simple purification steps, nonetheless, the reaction rate is slow and it is not cost effective. Enzymes used as catalysts are also susceptible to alcohol and temperature, which can lead to its deactivation and subsequently reducing the yield of biodiesel.

In a recent study, a single-step process of direct transesterification method by means of successive usage of acid-base catalysis was developed to produce biodiesel from the crude oil of Pongamia pinnata and the process was evaluated with the conservative two-step esterification-transesterification technique [49]. The direct transesterification method utilizes the combination of methanol and sodium methoxide as the base catalyst and boron trifluoride as the acid catalyst. The production time of the direct transesterification process was reduced by 1.5 times to obtain the final biodiesel product. It was reported that no significant difference was observed between the quality of the fuel produced from both the esterification-transesterification and direct transesterification methods. The potential reaction among sodium methoxide in methanol and a vegetable oil is fast and is frequently utilised as a quick method for free fatty acids esterification [123]. This shows that the direct transesterification method is very promising method that can reduce the processing time, lessen the solvent needed and be applied to other non-edible feedstock as well [124].

Recent researches have explored the implementation of advanced biofuel production based on the rapid and risk-reducing industrialisation of nano-catalytic processes. New green biocatalysts are being developed to reduce the reaction time and cost compared to using the existing catalysts. One example is heterogeneous catalyst which is environmentally friendly and recyclable. They are capable of producing high yield of biodiesel and can be separated from the liquid easily apart from possess a long lifespan [51, 125]. A study by Tahvildari et al. used $\mathrm{CaO}$ and $\mathrm{MgO}$ heterogenic nano-catalyst coupling for 
the transesterification reaction to produce biodiesel from recycled cooking oil. It was described that nano-MgO was not capable of catalysing the transesterification by itself, but when used together with nano- $\mathrm{CaO}$, it could achieve significant enhancement in the yield. The combined catalyst had a high contact area and its repeatability was much better compared to using nano- $\mathrm{CaO}$ alone. A higher proportion of nano- $\mathrm{CaO}$ to nano- $\mathrm{MgO}$ also lead to more biodiesel production [50]. Another work by Jadhav and Tandale (2018) used nano-MgO, nano- $\mathrm{ZnO}$ and nano- $\mathrm{SiO}_{2}$ for biodiesel production from Mangifera indica oil. The results indicated that nano- $\mathrm{SiO}_{2}$ had the highest yield due to its super-acidity characteristics that had a positive effect on the catalytic reactivity. Nano- $\mathrm{SiO}_{2}$ also performs as a robust activators which can stimulate the reaction to obtain maximum yield [51]. The development of Ag/bauxite nanocomposites for biodiesel production has also been performed [52]. The large porous structure of the nanocomposite resulted in increased catalytic activity through increasing the greater surface area and contact between alcohol and oil, which lead to higher efficiency of the transesterification reaction. In summary, heterogeneous catalysts can provide an efficient and effective conversion of feedstock to biodiesel with a beneficial attribute of recyclability [126]. The fabrication of nanocomposites, containing both acid and base sites, higher surface to volume ratio and larger pore distribution, can also contribute to the commercialization of biodiesel production.

\section{Supercritical fluid method}

Supercritical fluid extraction (SFE) is an extraction process that uses supercritical carbon dioxide $\left(\mathrm{SC}-\mathrm{CO}_{2}\right)$ as the solvent. The $\mathrm{SC}-\mathrm{CO}_{2}$ extraction technique is a valuable tool to increase the yield and selectivity profile in the extraction of organic compounds from plants [127]. SFE has few benefits compared to conventional extraction methods which include the higher selectivity, shorter processing time and use of non-toxic solvents. Since the $\mathrm{CO}_{2}$ is a gas at room temperature and pressure, this technique does not need further processing steps for solvent separation, unlike conventional extraction processes which require separation of the solvents that causes the degradation of the desired compounds. The other supercritical solvents that can be used are methanol, ethanol, propanol, acetone, methyl acetate, and dimethyl carbonate. When these solvents reach the supercritical state, the hydrogen bonds in the solvents will be greatly reduced, leading to a drop in the polarity and dielectric constant which allows the molecules of the solvents to act as free monomers. Due to this phenomenon, the supercritical solvents can solvate non-polar triglycerides into a homogenous liquid phase to produce FAME and diglycerides.
$\mathrm{SC}-\mathrm{CO}_{2}$ has moderate critical pressure, i.e. 73.9 bar, which allows for an appropriate compression cost, along with its low critical temperature, i.e. $31.1^{\circ} \mathrm{C}$, this solvent can successfully extract thermally sensitive lipid fractions without degrading them. The $\mathrm{SC}-\mathrm{CO}_{2}$ also facilitates a safe extraction process as it does not react easily and has low flammability [127]. Supercritical alcohols such as supercritical methanol have also shown promising results for the production of biodiesel. The solvent polarity of these supercritical fluids can be tuned and controlled by adjusting the temperature and pressure. In methanol, the hydrogen bond network is broken under supercritical conditions, this reduction in hydrogen bonding will encourage a stronger direct nucleophilic attack by methanol on the carbonyl group. The dielectric constant of methanol also decreases at supercritical state and this will lead to an elevation in reaction rate [128]. Nevertheless, the selection of alcohol is vital for evaluating the cost and performance. Alcohols like ethanol are easily obtained from agricultural renewable feedstock and are preferable to methanol. Ethanol has a higher dissolving power for oils and is a more suitable alcohol for the transesterification of vegetable oils. Besides, alcohol with higher or branched structure is able to produce fuels with better properties. The extra carbon atom provided by ethanol can slightly increase the heat content and cetane number [128].

SFE has been used to extract lipids from various biomass which includes spent coffee grounds using $\mathrm{SC}-\mathrm{CO}_{2}$ [34], soybean using $\mathrm{SC}-\mathrm{CO}_{2}$ [129], linseed using supercritical-ethanol [130], residual corn material using $\mathrm{SC}-\mathrm{CO}_{2} \quad$ [55], organosolv lignin using supercritical-ethanol [131], shrimp waste using $\mathrm{SC}-\mathrm{CO}_{2}$ [132], and white pinewood [133]. Apart from that, SFE has been extensively studied for the extraction of lipid from third generation feedstock as well. Lipid from milk was also extracted using a supercritical anti-solvent fractionation technology (SAFT). The SAFT is a versatile process which consists of a water-miscible organic solvent and water. The resulting solution from the process undergoes extraction using a supercritical solvent. High lipid yields was obtained by SAFT using dimethyl ether and the lipid contents were found to be around $70 \%$ neutral and 30\% phospholipids [134].

Supercritical transesterification is a simplified biofuel production process that requires no catalyst. This technique was developed to overcome certain drawbacks associated with catalysed transesterification, such as long reaction time, catalyst poisoning, catalyst regeneration, high operation cost, saponification and biodiesel washing. Supercritical transesterification does not require catalysts as it utilizes the supercritical operating conditions, thereby reducing the complexity and costs associated with the catalyst usage [53]. However, high temperature and pressure is 
required to create the supercritical conditions, where this will require costly materials for the construction of the equipment to withstand the high operating conditions. Despite this, the supercritical process still has many advantages and can handle a wide range of feedstock. The design of the transesterification reactor can also affect the reaction process and biodiesel yield. A novel spiral reactor was designed by Farobie and Matsumura [54] to produce biodiesel via non-catalytic transesterification. The spiral reactor was designed to tackle the heat recovery problem in commercial production. It was reported that the FAME yield obtained using the spiral reactor rose while the temperature and reaction time increased, where better yield was obtained compared to using a batch reactor at the same reaction conditions. Supercritical fluid has been used in commercial production of biodiesel, which indicates its scalability potential and its readiness to be deployed as a feasible technology.

\section{Conversion of biomass to bioelectricity}

Apart from biofuel production, bioenergy in the form of bioelectricity that can be sourced from renewable feedstock are part of the spectrum of energy technologies. The conversion of agricultural and forest resides to biomass feedstock for electricity generation and district heating is developing as a potential form of bioenergy. Bioelectricity can be mainly produced through the combustion of lignocellulose feedstock which is obtained from biomass sources such as agricultural products and residues, plantation forests, sawmill residue and native forests. A study on the possibility of bioelectricity production from biomass for greenhouse gas emission reduction in Australia reported the use of lignocellulose from forestry and agricultural biomass to generate electricity via direct combustion [135]. The electricity production from the current forestry and agricultural production systems used contributed to about $15 \%$ of the country's total electricity generation, where upgrade to the first-generation technologies could enhance the electricity production by $9 \%$. The energy production systems were also capable of mitigating approximately $28 \%$ of electricity emission and $9 \%$ of the national emissions, which is a great impact on greenhouse gas emissions [135].

Another economic model was used to examine the prospective of combining the agriculture and forest sectors in the U.S. to enhance the production of renewable bioelectricity using simulated standards [136]. The model reported that the agricultural and forest sectors have the capacity to supply $10-20 \%$ of the future electricity consumption in the U.S., where the majority of the biomass feedstock will be obtained through energy crops and crops residues. The model also estimated the reduction of greenhouse gas emission to be about 27 million ton of $\mathrm{CO}_{2}$ in a period of 15 years. Besides that, the production prospects of crop residues in bioelectricity generation in China also play a major role in global bioenergy interest. The goal of biomass electricity capacity was set at 30,000 GW by 2020 in China. This would enable the more efficient use of China's agricultural biomass resources for electricity generation [137]. Another case study on the bioenergy supply potential in Amsterdam, Netherlands reported that the flexible bioenergy supply from urban waste stream could produce renewable energy in cities [138]. An urban electricity system model was developed to project future electric generation and it was discovered that about $1300-2800 \mathrm{t}$ of waste biomass per day was required in different scenarios. The average daily waste generated in the city of Amsterdam is about $1400 \mathrm{t}$ and this is subjected to change as waste generation would increase proportionally with urbanization and economic growth. These analyses play a role in supporting the policy-making in exploring potential bioenergy production from locally available biomass to contribute to a sustainable electricity system.

Bioelectricity can be produced through methods that are similarly used in other bioenergy productions, such as thermochemical conversion. One of the processes for bioelectricity generation is through combustion. Combustion is a chemical reaction where the biomass and oxygen are combined in a high temperature environment to form carbon dioxide, water and heat. The combustion process stores chemical energy in the fuel which is release to heat, light, radiation and other form of energy. Combustion transforms the biomass into char and volatiles, where these volatile gases react with oxygen to give heat. The bioelectricity generation through combustion works by the generation of steam from the heat generated from the combustion process. These steams will operate the steam turbine to produce electricity. Enhancement in the form of different types of turbine blade or operation mode of the steam turbine (reciprocating or screw-type turbines) can be done to improve the efficiency of power generated [139]. Another process for bioelectricity generation is through biomass gasification. Gasification extracts energy from solid fuel through gaseous conversion. Biomass wastes are converted into syngas and some heating compounds, together with the contaminants such as char, tar, chlorides and sulphides through gasification. The efficient utilization of syngas from gasification is deemed to be much better compared to combustion in terms of energy saving and ecological preservations [140]. The advantage of using gasifiers is that it can be utilized in rural areas with local biomass wastes, creating a possibility to reduce the issues of rural area electricity supply. The integration of both the combustion boilers with gasifiers could also enhance the electrical efficiency significantly, by up to $35 \%$ increase [139].

A recent promising technology for the conversion of biomass to electricity is the use of MFC. MFC technology 
involves the bioelectricity generation through the conversion of organic substrates by electrogenic bacteria under anaerobic conditions [58]. MFC consist of two chambers with a biotic anode and abiotic cathode that are separated by a proton exchange membrane. MFC can simultaneously treat various waste (food waste, household food waste and MSW) while generating electricity and represents a new source of renewable energy process. The current and power density produced through MFC can be altered by the operational conditions, including temperature, substrate concentration, $\mathrm{pH}$, loading rate, microorganisms activity, hydraulic retention time and static magnetic field [56]. In addition, many parameters relating to the electrode materials, architectures, cost effectiveness and also the membrane characteristics have been investigated to evaluate the improvement on electricity generation of MFC [57]. Akman et al. [56] reported that the utilization of $\mathrm{Ti}-\mathrm{TiO}_{2}$ electrode showed around 4 times higher power density compared to Pt electrode. Apart from that, the usage of food residue biomass as a substrate in the MFC process achieved the highest power density as well, indicating that the hydrolysis of food residue biomass could significantly enhance the performance of MFC [58]. MFC shows great potential as a green and sustainable process; its implementation can provide new insights for bioelectricity generation.

\section{Current challenge and future prospects}

The present review has revealed that many waste-to-bioenergy technological routes are made available to produce bioenergy from waste feedstock/substrates. Waste utilization is supposedly to be the most economical process for renewable energy production, coupled with its complementary benefit that is to clean the environment. Significant amounts of biomass residues and waste are produced inevitably from different sectors across world, and the waste could be a promising feedstock for bioenergy if efficient and economically viable technologies were developed. Still, there are several limitations to the development of biomass residues and waste as an immediate energy resource. First and foremost, waste-to-bioenergy production is still not as cost-competitive as fossil-based fuels, based on the current technologies developed. A feasibility study conducted by $\mathrm{Ng}$ et al. [141] demonstrated that the utilisation of MSW for bioenergy production is not economically profitable due to the high cost of technologies for incineration, gasification and pyrolysis. Tan et al. [142], in their analysis study of waste-to-bioenergy for MSW, concluded that gasification has relatively high operational cost (250,400 USD/d), and, in terms of decreasing cost, is followed by incinerator, landfill gas recovery system and lastly anaerobic digestion. The high energy required for waste pre-treatment process, purification of the biofuels produced, plant equipment set up, and reactor operation and maintenance, could limit the commercialization of waste-to-bioenergy technologies. Therefore, the process optimization is being the research focus nowadays to increase the production yield and process efficiency.

To some extents, the implementation of waste-to-bioenergy approach should aid to improve the environment by lessening the amount of waste that must be landfilled. However, the processing of waste-to-bioenergy might lead to the release of undesirable and harmful by-products to atmosphere. For an example, the emissions of trace organics such as furans, polychlorinated dioxins, lead, mercury, and cadmium could be attributed to the inadequate design and/or poorly operated of MSW combustion systems for the generation of electricity [143]. The volatile elements such as mercury might get vaporised during the combustion process of MSW and might not able to be removed effectively using a particulate removal device [143]. Some measurements have been taken to prevent the emission of harmful compounds, include the adequate control of mixing and temperature of air/fuel and the avoidance of "quench" zones in the furnace. However, a satisfactory control technology to prevent the emission of harmful volatiles during waste-to-bioenergy processes should be continuously developed. The hazardous gas emission should be taken into consideration when selecting waste-to-bioenergy technology. For instances, an incinerator generally produces higher amounts of pollutants compare to anaerobic digestion. Anaerobic digestion could be an optimum choice for converting MSW that contains high moisture content if low demand for heat energy and cleaner technology are needed [142]. Lastly, proper waste classification is equally important to ensure higher energy recovery efficiency in power generation and minimize environmental impacts [144].

\section{Conclusions}

Biomass residues and waste can be converted into transportation fuels and bioelectricity using transesterification, thermochemical and biochemical pathways. The choice of process technology depends on the end product desired and the feedstocks. In general, thermochemical technology that employs thermal heat might not be sensitive to the biomass waste composition when compared to the biochemical strategies for the production of biofuels. Nevertheless, the production of biofuels from biomass waste is still considered more robust in material handling, transportation, and conversion technology, when compared to traditional editable food crops-based biofuels. Still, on-going research studies are devoted to fill up the inadequacies of the existing technologies and improve the efficiency and economics of the production technologies employed. 


\section{Abbreviations}

DESs: Deep eutectic solvents; FAME: Fatty acids methyl esters; HDO: Hydrodeoxygenation; HGF: Hot gas filtration; HTL: Hydrothermal liquefaction; MFC: Microbial fuel cells; MSW: Municipal solid waste; PHWW: Post-hydrothermal liquefaction wastewater; SAFT: Supercritical anti-solvent fractionation technology; SC-CO2: Supercritical carbon dioxide; SCW: Subcritical water; SFE: Supercritical fluid extraction

\section{Acknowledgements}

Not applicable.

\section{Funding}

This work was supported by the Fundamental Research Grant Scheme, Malaysia [FRGS/1/2015/SG05/UNIM/03/1]; the Ministry of Science and Technology, Malaysia [MOSTI02-02-12-SF0256]; and the Prototype Research Grant Scheme, Malaysia [PRGS/2/2015/SG05/UNIM/03/1]. The founding sponsors had no role in the design of the study, in the collection, analyses, or interpretation of data, in the writing of the manuscript, and in the decision to publish the results. Any opinions, findings and conclusions or recommendations expressed in this material are those of the authors and do not necessarily reflect those of the funding agencies.

\section{Availability of data and materials}

Data sharing not applicable to this article as no datasets were generated or analysed during the current study.

\section{Authors' contributions}

SYL contributed in designing the work, and drafted sections of abstract, 1.0, 2.0, 4.0 and 5.0. RS contributed in drafting 3.0 and 3.1 sections. KWC drafted 3.3 and 3.4 sections. CHT drafted section 3.2. PLS, RK and DTC have revised the writing. All authors approved the submitted version and agreed both to be personally accountable for the author's own contributions and to ensure that questions related to the accuracy or integrity of any part of the work.

\section{Competing interests}

The corresponding author declares himself as a member of the editorial board of this journal. Other authors declare that they have no competing interests.

\section{Publisher's Note}

Springer Nature remains neutral with regard to jurisdictional claims in published maps and institutional affiliations.

\begin{abstract}
Author details
${ }^{1}$ Department of Chemical Engineering, Faculty of Engineering and Science, Universiti Tunku Abdul Rahman, Sungai Long Campus, 43000 Kajang, Selangor, Malaysia. ${ }^{2}$ Institute of Biological Sciences, Faculty of Science, University of Malaya, 50603 Kuala Lumpur, Malaysia. ${ }^{3}$ Department of Chemical and Environmental Engineering, Faculty of Engineering, University of Nottingham Malaysia Campus, 43500 Semenyih, Selangor, Malaysia. ${ }^{4}$ Department of Chemical Engineering, School of Civil and Chemical Engineering, VIT University, Vellore 632014, India. ${ }^{5}$ Department of Chemical Engineering, Khalifa University of Science and Technology, The Petroleum Institute, Abu Dhabi, United Arab Emirates. ${ }^{6}$ Faculty of Biology, Hanoi National University of Education, Hanoi, Vietnam. ${ }^{7}$ Centre for Molecular Medicine Norway (NCMM), Nordic EMBL Partnership, University of Oslo and
\end{abstract} Oslo University Hospital, Oslo, Norway.

\section{Received: 7 December 2018 Accepted: 9 April 2019}

\section{Published online: 16 May 2019}

\section{References}

1. Naik SN, Goud W, Rout PK, Dalai AK. Production of first and second generation biofuels: a comprehensive review. Renew Sust Energ Rev. 2010; 14:578-97. https://doi.org/10.1016/j.rser.2009.10.003.

2. Sims REH, Mabee W, Saddler JN, Taylor M. An overview of second generation biofuel technologies. Bioresour Technol. 2010;101:1570-80. https://doi.org/10.1016/j.biortech.2009.11.046.

3. Speight JG, Singh K. Environmental Management of Energy from biofuels and biofeedstocks. Hoboken: John Wiley \& Sons, Inc; 2014. https://doi.org/ 10.1002/9781118915141
4. Chen D, Yin L, Wang H, He P. Reprint of: pyrolysis technologies for municipal solid waste: a review. Waste Manag. 2015;37:116-36. https://doi. org/10.1016/j.wasman.2015.01.022.

5. Li A, Antizar-Ladislao B, Khraisheh M. Bioconversion of municipal solid waste to glucose for bio-ethanol production. Bioprocess Biosyst Eng. 2007;30:18996. https://doi.org/10.1007/s00449-007-0114-3.

6. Ragauskas AJ, Nagy M, Kim DH, Eckert CA, Hallett JP, Liotta CL. From wood to fuels: integrating biofuels and pulp production. Ind Biotechnol. 2006;2: 55-65. https://doi.org/10.1089/ind.2006.2.55.

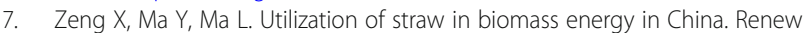
Sust Energ Rev. 2007;11:976-87. https://doi.org/10.1016/j.rser.2005.10.003.

8. Qureshi N, Saha BC, Hector RE, Dien B, Hughes S, Liu S, et al. Production of butanol (a biofuel) from agricultural residues: part II - use of corn Stover and switchgrass hydrolysates. Biomass Bioenergy. 2010;34:566-71. https:// doi.org/10.1016/j.biombioe.2009.12.023.

9. Cai D, Li P, Luo Z, Qin P, Chen C, Wang Y, et al. Effect of dilute alkaline pretreatment on the conversion of different parts of corn stalk to fermentable sugars and its application in acetone-butanol-ethanol fermentation. Bioresour Technol. 2016;211:117-24. https://doi.org/10.1016/j. biortech.2016.03.076.

10. Krishnan C, Sousa L d C, Jin M, Chang L, Dale BE, Balan V. Alkali-based AFEX pretreatment for the conversion of sugarcane bagasse and cane leaf residues to ethanol. Biotechnol Bioeng. 2010;107:441-50. https://doi.org/10.1002/bit.22824.

11. Chandel AK, da Silva SS, Carvalho W, Singh OV. Sugarcane bagasse and leaves: foreseeable biomass of biofuel and bio-products. J Chem Technol Biotechnol. 2012;87:11-20. https://doi.org/10.1002/jctb.2742.

12. Inyang M, Gao B, Pullammanappallil P, Ding W, Zimmerman AR. Biochar from anaerobically digested sugarcane bagasse. Bioresour Technol. 2010; 101:8868-72. https://doi.org/10.1016/j.biortech.2010.06.088.

13. Cerveró JM, Skovgaard PA, Felby C, Sørensen HR, Jørgensen H. Enzymatic hydrolysis and fermentation of palm kernel press cake for production of bioethanol. Enzym Microb Technol. 2010;46:177-84. https://doi.org/10.1016/ j.enzmictec.2009.10.012.

14. Jørgensen $H$, Sanadi AR, Felby C, Lange NEK, Fischer M, Ernst S. Production of ethanol and feed by high dry matter hydrolysis and fermentation of palm kernel press cake. Appl Biochem Biotechnol. 2010;161:318-32. https:// doi.org/10.1007/s12010-009-8814-6.

15. Zhang $Y$, Dubé M, McLean D, Kates M. Biodiesel production from waste cooking oil: 2. Economic assessment and sensitivity analysis. Bioresour Technol. 2003;90:229-40. https://doi.org/10.1016/S0960-8524(03)00150-0.

16. Zhang Y, Dubé MA, McLean DD, Kates M. Biodiesel production from waste cooking oil: 1. Process design and technological assessment. Bioresour Technol. 2003;89:1-16. https://doi.org/10.1016/S0960-8524(03)00040-3.

17. Supple B, Howard-Hildige R, Gonzalez-Gomez E, Leahy JJ. The effect of steam treating waste cooking oil on the yield of methyl ester. J Am Oil Chem Soc. 2002;79:175-8. https://doi.org/10.1007/s11746-002-0454-1.

18. Talebian-Kiakalaieh A, Amin NAS, Mazaheri H. A review on novel processes of biodiesel production from waste cooking oil. Appl Energy. 2013;104:683710. https://doi.org/10.1016/j.apenergy.2012.11.061.

19. Meng $X$, Chen $G$, Wang Y. Biodiesel production from waste cooking oil via alkali catalyst and its engine test. Fuel Process Technol. 2008;89:851-7. https://doi.org/10.1016/j.fuproc.2008.02.006.

20. Phan AN, Phan TM. Biodiesel production from waste cooking oils. Fuel. 2008;87:3490-6. https://doi.org/10.1016/j.fuel.2008.07.008.

21. JACOBSON K, GOPINATH R, MEHER L, DALAI A. Solid acid catalyzed biodiesel production from waste cooking oil. Appl Catal B Environ. 2008;85: 86-91. https://doi.org/10.1016/j.apcatb.2008.07.005.

22. Bansemir A, Blume M, Schröder S, Lindequist U. Screening of cultivated seaweeds for antibacterial activity against fish pathogenic bacteria. Aquaculture. 2006;252:79-84. https://doi.org/10.1016/j.aquaculture.2005.11.051.

23. Ngo SI, Nguyen TDB, II LY, Song BH, Do LU, Choi YT, et al. Performance evaluation for dual circulating fluidized-bed steam gasifier of biomass using quasi-equilibrium three-stage gasification model. Appl Energy. 2011;88: 5208-20. https://doi.org/10.1016/j.apenergy.2011.07.046.

24. Mazzoni L, Ahmed R, Janajreh I. Plasma gasification of two waste streams: municipal solid waste and hazardous waste from the oil and gas industry. Energy Procedia. 2017;105:4159-66. https://doi.org/10.1016/j.egypro.2017.03.882.

25. de Oliveira JL, da Silva JN, Martins MA, Pereira EG, da Conceição Trindade Bezerra e Oliveira M. Gasification of waste from coffee and eucalyptus production as an alternative source of bioenergy in Brazil. Sustain Energy Technol Assessments. 2018;27 May 2017:159-66. 
26. Liu L, Huang Y, Cao J, Liu C, Dong L, Xu L, et al. Experimental study of biomass gasification with oxygen-enriched air in fluidized bed gasifier. Sci Total Environ. 2018;626:423-33.

27. Chen G, Liu F, Guo X, Zhang Y, Yan B, Cheng Z, et al. Co-gasification of acid hydrolysis residues and sewage sludge in a downdraft fixed gasifier with $\mathrm{CaO}$ as an in-bed additive. Energy and Fuels. 2018;32:5893-900.

28. López Barreiro D, Riede S, Hornung U, Kruse A, Prins W. Hydrothermal liquefaction of microalgae: effect on the product yields of the addition of an organic solvent to separate the aqueous phase and the biocrude oil. Algal Res. 2015:12:206-12. https://doi.org/10.1016/j.algal.2015.08.025.

29. Alhassan Y, Kumar N, Bugaje IM. Hydrothermal liquefaction of de-oiled Jatropha curcas cake using deep eutectic solvents (DESs) as catalysts and co-solvents. Bioresour Technol. 2016;199:375-81. https://doi.org/10.1016/j. biortech.2015.07.116

30. Lu J, Zhang J, Zhu Z, Zhang Y, Zhao Y, Li R, et al. Simultaneous production of biocrude oil and recovery of nutrients and metals from human feces via hydrothermal liquefaction. Energy Convers Manag. 2017;134:340-6. https:// doi.org/10.1016/j.enconman.2016.12.052.

31. Couto EA, Pinto F, Varela F, Reis A, Costa P, Calijuri ML. Hydrothermal liquefaction of biomass produced from domestic sewage treatment in highrate ponds. Renew Energy. 2018;118:644-53. https://doi.org/10.1016/j. renene.2017.11.041.

32. Rahman QM, Zhang B, Wang L, Joseph G, Shahbazi A. A combined fermentation and ethanol-assisted liquefaction process to produce biofuel from Nannochloropsis sp. Fuel. 2019;238 October 2018:159-65. https://doi. org/10.1016/j.fuel.2018.10.116.

33. Li R, Liu D, Zhang Y, Duan N, Zhou J, Liu Z, et al. Improved methane production and energy recovery of post-hydrothermal liquefaction waste water via integration of zeolite adsorption and anaerobic digestion. Sci Total Environ. 2019;651:61-9. https://doi.org/10.1016/j.scitotenv.2018.09.175.

34. Pattiya A, Suttibak S. Fast pyrolysis of sugarcane residues in a fluidised bed reactor with a hot vapour filter. J Energy Inst. 2017;90:110-9.

35. Merdun H, Sezgin IV. Products distribution of catalytic co-pyrolysis of greenhouse vegetable wastes and coal. Energy. 2018;162:953-63.

36. Cho DW, Tsang DCW, Kim S, Kwon EE, Kwon G, Song H. Thermochemical conversion of cobalt-loaded spent coffee grounds for production of energy resource and environmental catalyst. Bioresour Technol. 2018;270 August: 346-51. https://doi.org/10.1016/j.biortech.2018.09.046.

37. Jahromi $\mathrm{H}$, Agblevor FA. Hydrodeoxygenation of aqueous-phase catalytic pyrolysis oil to liquid hydrocarbons using multifunctional nickel catalyst. Ind Eng Chem Res. 2018;57:13257-68.

38. Boscagli C, Tomasi Morgano M, Raffelt K, Leibold H, Grunwaldt JD. Influence of feedstock, catalyst, pyrolysis and hydrotreatment temperature on the composition of upgraded oils from intermediate pyrolysis. Biomass Bioenergy. 2018;116 June:236-48.

39. Passos F, Carretero J, Ferrer I. Comparing pretreatment methods for improving microalgae anaerobic digestion: thermal, hydrothermal, microwave and ultrasound. Chem Eng J. 2015;279:667-72. https://doi.org/ 10.1016/j.cej.2015.05.065.

40. Solé-Bundó M, Carrère H, Garfí M, Ferrer I. Enhancement of microalgae anaerobic digestion by thermo-alkaline pretreatment with lime $(\mathrm{CaO})$. Algal Res. 2017;24:199-206. https://doi.org/10.1016/j.algal.2017.03.025.

41. Molinuevo-Salces B, Mahdy A, Ballesteros M, González-Fernández C. From piggery wastewater nutrients to biogas: microalgae biomass revalorization through anaerobic digestion. Renew Energy. 2016;96:1103-10. https://doi. org/10.1016/j.renene.2016.01.090.

42. El-Dalatony MM, Kurade MB, Abou-Shanab RAl, Kim H, Salama E-S, Jeon B-H. Long-term production of bioethanol in repeated-batch fermentation of microalgal biomass using immobilized Saccharomyces cerevisiae. Bioresour Technol. 2016;219:98-105. https://doi.org/10.1016/j.biortech.2016.07.113.

43. Hwang J-H, Kabra AN, Ji M-K, Choi J, El-Dalatony MM, Jeon B-H. Enhancement of continuous fermentative bioethanol production using combined treatment of mixed microalgal biomass. Algal Res. 2016;17:14-20. https://doi.org/10.1016/j.algal.2016.03.029.

44. Gao K, Orr V, Rehmann L. Butanol fermentation from microalgae-derived carbohydrates after ionic liquid extraction. Bioresour Technol. 2016;206:7785. https://doi.org/10.1016/j.biortech.2016.01.036.

45. Sengmee D, Cheirsilp B, Suksaroge TT, Prasertsan P. Biophotolysis-based hydrogen and lipid production by oleaginous microalgae using crude glycerol as exogenous carbon source. Int J Hydrog Energy. 2017;42:1970-6. https://doi.org/10.1016/j.ijhydene.2016.10.089.
46. Oncel S, Kose A. Comparison of tubular and panel type photobioreactors for biohydrogen production utilizing Chlamydomonas reinhardtii considering mixing time and light intensity. Bioresour Technol. 2014;151: 265-70. https://doi.org/10.1016/j.biortech.2013.10.076.

47. Giannelli L, Torzillo G. Hydrogen production with the microalga Chlamydomonas reinhardtii grown in a compact tubular photobioreactor immersed in a scattering light nanoparticle suspension. Int J Hydrog Energy. 2012;37:16951-61. https://doi.org/10.1016/j.ijhydene.2012.08.103.

48. Muller EEL, Sheik AR, Wilmes P. Lipid-based biofuel production from wastewater. Curr Opin Biotechnol. 2014;30:9-16. https://doi.org/10.1016/j. copbio.2014.03.007.

49. Yunus Khan TM, Badruddin IA, Ankalgi RF, Badarudin A, Hungund BS, Ankalgi FR. Biodiesel production by direct transesterification process via sequential use of Acid-Base catalysis. Arab J Sci Eng. 2018;43:5929-36. https://doi.org/10.1007/s13369-018-3078-5.

50. Tahvildari K, Anaraki YN, Fazaeli R, Mirpanji S, Delrish E. The study of CaO and $\mathrm{MgO}$ heterogenic nano-catalyst coupling on transesterification reaction efficacy in the production of biodiesel from recycled cooking oil. J Environ Heal Sci Eng. 2015;13:73. https://doi.org/10.1186/s40201-015-0226-7.

51. Jadhav SD, Tandale MS. Optimization of transesterification process using homogeneous and nano-heterogeneous catalysts for biodiesel production from Mangifera indica oil. Environ Prog Sustain Energy. 2018;37:533-45. https://doi.org/10.1002/ep.12690.

52. Bet-Moushoul E, Farhadi K, Mansourpanah Y, Molaie R, Forough M, Nikbakht AM. Development of novel ag/bauxite nanocomposite as a heterogeneous catalyst for biodiesel production. Renew Energy. 2016;92:12-21. https://doi. org/10.1016/j.renene.2016.01.070.

53. Deshpande SR, Sunol AK, Philippidis G. Status and prospects of supercritical alcohol transesterification for biodiesel production. Wiley Interdiscip Rev Energy Environ. 2017;6:e252. https://doi.org/10.1002/wene.252.

54. Farobie O, Matsumura Y. Biodiesel production in supercritical methanol using a novel spiral reactor. Procedia Environ Sci. 2015;28:204-13. https:// doi.org/10.1016/j.proenv.2015.07.027.

55. Toribio L, Bernal JL, Nozal MJ, Arnaiz E, Bernal J. Sequential supercritical fluid extraction of lipids. Application to the Obtention of the fatty acid profile of some genetically modified varieties of corn. Food Anal Methods. 2011:4: 196-202. https://doi.org/10.1007/s12161-010-9157-1.

56. Akman D, Cirik K, Ozdemir S, Ozkaya B, Cinar O. Bioelectricity generation in continuously-fed microbial fuel cell: effects of anode electrode material and hydraulic retention time. Bioresour Technol. 2013;149:459-64. https://doi. org/10.1016/j.biortech.2013.09.102.

57. Chiu H, Pai T, Liu M, Chang C, Lo F, Chang T, et al. Electricity production from municipal solid waste using microbial fuel cells. Waste Manag Res. 2016;34:619-29. https://doi.org/10.1177/0734242X16649681.

58. Chatzikonstantinou D, Tremouli A, Papadopoulou K, Kanellos G, Lampropoulos I, Lyberatos G. Bioelectricity production from fermentable household waste in a dual-chamber microbial fuel cell. Waste Manag Res. 2018;36:0734242X1879693. https://doi.org/10.1177/0734242X18796935

59. Goyal HB, Seal D, Saxena RC. Bio-fuels from thermochemical conversion of renewable resources: a review. Renew Sust Energ Rev. 2008;12:504-17.

60. Uzoejinwa BB, He X, Wang S, El-Fatah Abomohra A, Hu Y, Wang Q. Copyrolysis of biomass and waste plastics as a thermochemical conversion technology for high-grade biofuel production: recent progress and future directions elsewhere worldwide. Energy Convers Manag. 2018;163 February: 468-92. https://doi.org/10.1016/j.enconman.2018.02.004.

61. Ahmad AA, Zawawi NA, Kasim FH, Inayat A, Khasri A. Assessing the gasification performance of biomass: a review on biomass gasification process conditions, optimization and economic evaluation. Renew Sust Energ Rev. 2016;53:1333-47.

62. Sansaniwal SK, Pal K, Rosen MA, Tyagi SK. Recent advances in the development of biomass gasification technology: a comprehensive review. Renew Sust Energ Rev. 2017;72 December 2015:363-84.

63. Pandey A, Bhaskar T, Stocker M, Sukumaran R. Recent advances in thermochemical conversion of biomass. In: Pandey A, Bhaskar T, Stocker M, Sukumaran R, editors. Recent Advances in Thermo-Chemical Conversion of Biomass. Netherlands: Elsevier Inc; 2015.

64. Watson J, Zhang Y, Si B, Chen WT, de Souza R. Gasification of biowaste: a critical review and outlooks. Renew Sust Energ Rev. 2018:83 August 2017:1-17.

65. Ogi T, Nakanishi M, Fukuda Y, Matsumoto K. Gasification of oil palm residues (empty fruit bunch) in an entrained-flow gasifier. Fuel. 2013;104:2835. https://doi.org/10.1016/j.fuel.2010.08.028. 
66. Olwa J, Öhman M, Esbjörn P, Boström D, Okure M, Kjellström B. Potassium retention in updraft gasification of wood. Energy Fuel. 2013;27:6718-24. https://doi.org/10.1021/ef401179f.

67. Hosseinpour Vardin F, Najafi B. Developing a novel downdraft fixed bed gasifier for hydrogen production from sawdust to improve an SI engine exhaust emissions. Renew Energy Focus. 2018;27:88-96. https://doi.org/10. 1016/j.ref.2018.07.007.

68. Pranolo SH, Tasmiul Khoir M, Fahreza Pradhana M. Production of clean synthetic gas from palm shell in a fixed bed gasifier with recycle system of producer gas. MATEC Web Conf. 2018;197:9004. https://doi.org/10.1051/ matecconf/201819709004.

69. Pecate S, Kessas SA, Morin M, Hemati M. Beech wood gasification in a dense and fast internally circulating fluidized bed. Fuel. 2019;236 September 2018:554-73. https://doi.org/10.1016/j.fuel.2018.09.025.

70. Wilk V, Hofbauer H. Conversion of fuel nitrogen in a dual fluidized bed steam gasifier. Fuel. 2013;106:793-801. https://doi.org/10.1016/j.fuel.2012.12.056.

71. Yang S, Li B, Zheng J, Kankala RK. Biomass-to-methanol by dual-stage entrained flow gasification: design and techno-economic analysis based on system modeling. J Clean Prod. 2018;205:364-74. https://doi.org/10.1016/j. jclepro.2018.09.043.

72. Pambudi NA, Laukkanen T, Syamsiro M, Gandidi IM. Simulation of Jatropha curcas shell in gasifier for synthesis gas and hydrogen production. J Energy Inst. 2017;90:672-9. https://doi.org/10.1016/j.joei.2016.07.010.

73. Wu Z, Meng H, Luo Z, Chen L, Zhao J, Wang S. Performance evaluation on co-gasification of bituminous coal and wheat straw in entrained flow gasification system. Int J Hydrog Energy. 2017;42:18884-93. https://doi.org/ 10.1016/j.jhydene.2017.05.144.

74. Mazzoni L, Janajreh I. Plasma gasification of municipal solid waste with variable content of plastic solid waste for enhanced energy recovery. Proc 2016 Int Renew Sustain Energy Conf IRSEC 2016. 2017:42:907-12. https://doi. org/10.1109/IRSEC.2016.7984049.

75. Messerle VE, Mosse AL, Ustimenko AB. Processing of biomedical waste in plasma gasifier. Waste Manag. 2018;79:791-9. https://doi.org/10.1016/j. wasman.2018.08.048.

76. Salimi M, Tavasoli A, Balou S, Hashemi H, Kohansal K. Influence of promoted bimetallic Ni-based catalysts and micro/Mesopores carbonaceous supports for biomass hydrothermal conversion to $\mathrm{H} 2$-rich gas. Appl Catal B Environ. 2018;239:383-97. https://doi.org/10.1016/j.apcatb.2018.08.039.

77. Dimitriadis A, Bezergianni S. Hydrothermal liquefaction of various biomass and waste feedstocks for biocrude production: a state of the art review. Renew Sust Energ Rev. 2017;68 May 2016:113-25. https://doi.org/10.1016/j. rser.2016.09.120.

78. Langholtz MH, Stokes BJ, Eaton LM. 2016 billion-ton report: advancing domestic resources for a thriving bioeconomy; 2016. https://doi.org/10. 2172/1271651.

79. Kumar S, Gupta RB. Hydrolysis of microcrystalline cellulose in subcritical and supercritical water in a continuous flow reactor. Ind Eng Chem Res. 2008:47: 9321-9. https://doi.org/10.1021/ie801102j.

80. Costanzo W, Hilten R, Jena U, Das KC, Kastner JR. Effect of low temperature hydrothermal liquefaction on catalytic hydrodenitrogenation of algae biocrude and model macromolecules. Algal Res. 2016;13:53-68. https://doi. org/10.1016/j.algal.2015.11.009.

81. Li G, Wang Z, Zhao R. Research progress of oil making from sewage sludge by direct thermochemistry liquefaction technology. J Tianjin Univ Sci Technol. 2009:24:74-8.

82. Qian L, Wang S, Savage PE. Hydrothermal liquefaction of sewage sludge under isothermal and fast conditions. Bioresour Technol. 2017:232:27-34. https://doi.org/10.1016/j.biortech.2017.02.017.

83. Li R, Li B, Yang T, Kai X, Wang W, Jie $Y$, et al. Sub-supercritical liquefaction of rice stalk for the production of bio-oil: effect of solvents. Bioresour Technol. 2015;198:94-100. https://doi.org/10.1016/j.biortech.2015.08.088.

84. Biller P, Johannsen I, dos Passos JS, Ottosen LDM. Primary sewage sludge filtration using biomass filter aids and subsequent hydrothermal coliquefaction. Water Res. 2018;130:58-68. https://doi.org/10.1016/j.watres. 2017.11.048

85. Wu S, Liu F, Huang S, Wu Y, Gao J. Direct $n$-hexane extraction of wet sewage sludge at thermal and pressurized conditions: a preliminary investigation on its process and product characteristics. Fuel Process Technol. 2017;156:90-7. https://doi.org/10.1016/j.fuproc.2016.07.020.

86. Sun Z, Bottari G, Afanasenko A Stuart MCA Deuss PJ, Fridrich B, et al. Complete lignocellulose conversion with integrated catalyst recycling yielding valuable aromatics and fuels. Nat Catal. 2018;1:82-92. https://doi. org/10.1038/s41929-017-0007-z.

87. Tran Nguyen PL, Go AW, Huynh LH, Ju Y-H. A study on the mechanism of subcritical water treatment to maximize extractable cellular lipids. Biomass Bioenergy. 2013;59:532-9. https://doi.org/10.1016/j.biombioe.2013.08.031.

88. Yang T, Liu X, Li R, Li B, Kai X. Hydrothermal liquefaction of sewage sludge to produce bio-oil: effect of co-pretreatment with subcritical water and mixed surfactants. J Supercrit Fluids. 2019;144 October 2018:28-38. https:// doi.org/10.1016/j.supflu.2018.10.005

89. Yu G, Zhang Y, Schideman L, Funk T, Wang Z. Distributions of carbon and nitrogen in the products from hydrothermal liquefaction of low-lipid microalgae. Energy Environ Sci. 2011;4:4587. https://doi.org/10.1039/ clee01541a.

90. Chiaramonti D, Prussi M, Buffi M, Casini D, Rizzo AM. Thermochemical conversion of microalgae: challenges and opportunities. Energy Procedia. 2015;75:819-26. https://doi.org/10.1016/j.egypro.2015.07.142.

91. Dhyani $\mathrm{V}$, Bhaskar T. A comprehensive review on the pyrolysis of lignocellulosic biomass. Renew Energy. 2018;129:695-716. https://doi.org/10. 1016/j.renene.2017.04.035.

92. Bridgwater AV. Review of fast pyrolysis of biomass and product upgrading Biomass Bioenergy. 2012;38:68-94. https://doi.org/10.1016/j.biombioe.2011.01.048.

93. Jahirul M, Rasul M, Chowdhury A, Ashwath N. Biofuels production through biomass pyrolysis —a technological review. Energies. 2012;5:4952-5001. https://doi.org/10.3390/en5124952.

94. Rahman MM, Liu R, Cai J. Catalytic fast pyrolysis of biomass over zeolites for high quality bio-oil - a review. Fuel Process Technol. 2018;180 July:32-46. https://doi.org/10.1016/j.fuproc.2018.08.002.

95. Case PA, Wheeler MC, Desisto WJ. Effect of residence time and hot gas filtration on the physical and chemical properties of pyrolysis oil. Energy and Fuels. 2014:28:3964-9.

96. Ruiz M, Martin E, Blin J, Van De Steene L, Broust F. Understanding the secondary reactions of flash pyrolysis vapors inside a hot gas filtration unit. Energy and Fuels. 2017;31:13785-95.

97. Zhang X, Wang T, Ma L, Zhang Q, Jiang T. Hydrotreatment of bio-oil over Ni-based catalyst. Bioresour Technol. 2013;127:306-11. https://doi.org/10. 1016/j.biortech.2012.07.119.

98. Li N, Tompsett GA, Huber GW. Renewable high-octane gasoline by aqueous-phase Hydrodeoxygenation of C5 and C6 carbohydrates over Pt/ zirconium phosphate catalysts. ChemSusChem. 2010;3:1154-7. https://doi. org/10.1002/cssc.201000140.

99. Furimsky E. Catalytic hydrodeoxygenation. Appl Catal A Gen. 2000;199:14790. https://doi.org/10.1016/S0926-860X(99)00555-4.

100. Huber GW, Iborra S, Corma A. Synthesis of transportation fuels from biomass: chemistry, catalysts, and engineering. Chem Rev. 2006;106:404498. https://doi.org/10.1021/cr068360d.

101. Elkasabi Y, Mullen CA, Pighinelli ALMT, Boateng AA. Hydrodeoxygenation of fast-pyrolysis bio-oils from various feedstocks using carbon-supported catalysts. Fuel Process Technol. 2014;123:11-8. https://doi.org/10.1016/j. fuproc.2014.01.039.

102. Huang Y, Wei L, Zhao X, Cheng S, Julson J, Cao Y, et al. Upgrading pine sawdust pyrolysis oil to green biofuels by HDO over zinc-assisted $\mathrm{Pd} / \mathrm{C}$ catalyst. Energy Convers Manag. 2016;115:8-16. https://doi.org/10.1016/j. enconman.2016.02.049.

103. Wang W, Lee A. The study of producing " drop-in " fuels from agricultural waste through fast pyrolysis and catalytic hydro-processing. Renew Energy. 2019;133:1-10. https://doi.org/10.1016/j.renene.2018.10.022.

104. Perkins G, Bhaskar T, Konarova M. Process development status of fast pyrolysis technologies for the manufacture of renewable transport fuels from biomass. Renew Sustain Energy Rev. 2018;90 March:292-315. https:// doi.org/10.1016/j.rser.2018.03.048.

105. Hoff TC, Gardner DW, Thilakaratne R, Proano-Aviles J, Brown RC, Tessonnier JP. Elucidating the effect of desilication on aluminum-rich ZSM-5 zeolite and its consequences on biomass catalytic fast pyrolysis. Appl Catal A Gen. 2017:529:68-78. https://doi.org/10.1016/j.apcata.2016.10.009.

106. Sialve B, Bernet N, Bernard O. Anaerobic digestion of microalgae as a necessary step to make microalgal biodiesel sustainable. Biotechnol Adv. 2009;27:409-16. https://doi.org/10.1016/j.biotechadv.2009.03.001.

107. Brennan L, Owende P. Biofuels from microalgae-a review of technologies for production, processing, and extractions of biofuels and co-products. Renew Sust Energ Rev. 2010;14:557-77. https://doi.org/10.1016/j.rser.2009.10. 009. 
108. Cantrell KB, Ducey T, Ro KS, Hunt PG. Livestock waste-to-bioenergy generation opportunities. Bioresour Technol. 2008;99:7941-53. https://doi. org/10.1016/j.biortech.2008.02.061.

109. Grobbelaar J. Algal nutrition. In: Richmond A, editor. Handbook of microalgal culture: biotechnology and applied phycology. Oxford: Blackwell Publishing Ltd; 2004. p. 97-115. https://doi.org/10.1002/9780470995280.

110. Pavlostathis SG, Giraldo-Gomez E. Kinetics of anaerobic treatment: a critical review. Crit Rev Environ Control. 1991;21:411-90. https://doi.org/10.1080/ 10643389109388424.

111. Samson R, Leduyt A. Detailed study of anaerobic digestion ofSpirulina maxima algal biomass. Biotechnol Bioeng. 1986;28:1014-23. https://doi.org/ 10.1002/bit.260280712.

112. Günerken E, D'Hondt E, Eppink MHM, Garcia-Gonzalez L, Elst K, Wijffels RH. Cell disruption for microalgae biorefineries. Biotechnol Adv. 2015;33:243-60. https://doi.org/10.1016/j.biotechadv.2015.01.008.

113. González-Fernández C, Molinuevo-Salces B, García-González MC. Evaluation of anaerobic codigestion of microalgal biomass and swine manure via response surface methodology. Appl Energy. 2011;88:3448-53. https://doi. org/10.1016/j.apenergy.2010.12.035.

114. Saxena V, Tandon S, Singh K. Anaerobic digestion of green filamentous algae and waterhyacinth for methane production. Natl Acad Sci Lett. 1984;7: 283-4.

115. Yen $\mathrm{H}$, Brune D. Anaerobic co-digestion of algal sludge and waste paper to produce methane. Bioresour Technol. 2007;98:130-4. https://doi.org/10. 1016/j.biortech.2005.11.010

116. Bibi R, Ahmad Z, Imran M, Hussain S, Ditta A, Mahmood S, et al. Algal bioethanol production technology: a trend towards sustainable development. Renew Sust Energ Rev. 2017;71:976-85. https://doi.org/10. 1016/j.rser.2016.12.126.

117. John RP, Anisha GS, Nampoothiri KM, Pandey A. Micro and macroalgal biomass: a renewable source for bioethanol. Bioresour Technol. 2011;102: 186-93. https://doi.org/10.1016/j.biortech.2010.06.139.

118. Ghirardi M. Microalgae: a green source of renewable H2. Trends Biotechnol. 2000;18:506-11. https://doi.org/10.1016/S0167-7799(00)01511-0.

119. Melis A, Happe T. Hydrogen production. Green algae as a source of energy. Plant Physiol. 2001:127:740-8. https://doi.org/10.1104/pp.010498.

120. Kosourov S, Makarova V, Fedorov AS, Tsygankov A, Seibert M, Ghirardi ML. The effect of sulfur re-addition on $\mathrm{H} 2$ Photoproduction by sulfur-deprived green algae. Photosynth Res. 2005;85:295-305. https://doi.org/10.1007/ s11120-005-5105-0.

121. Kim JP, Kim K-R, Choi SP, Han SJ, Kim MS, Sim SJ. Repeated production of hydrogen by sulfate re-addition in sulfur deprived culture of Chlamydomonas reinhardtii. Int J Hydrog Energy. 2010;35:13387-91. https:// doi.org/10.1016/j.jhydene.2009.11.113.

122. Laurinavichene T, FEDOROV A, GHIRARDI M, SEIBERT M, TSYGANKOV A Demonstration of sustained hydrogen photoproduction by immobilized, sulfur-deprived Chlamydomonas reinhardtii cells. Int J Hydrog Energy. 2006; 31:659-67. https://doi.org/10.1016/j.ijhydene.2005.05.002.

123. Demirbas A. Comparison of transesterification methods for production of biodiesel from vegetable oils and fats. Energy Convers Manag. 2008:49:12530. https://doi.org/10.1016/j.enconman.2007.05.002.

124. Chew KW, Chia SR, Show PL, Ling TC, Chang JS. Biofuels from microbial lipids. In: Green Energy and Technology; 2018. p. 359-88. https://doi.org/10. 1007/978-981-10-7677-0_9.

125. Islam A, Taufiq-Yap YH, Chu C-M, Chan E-S, Ravindra P. Studies on design of heterogeneous catalysts for biodiesel production. Process Saf Environ Prot. 2013:91:131-44. https://doi.org/10.1016/j.psep.2012.01.002.

126. Sharma S, Saxena V, Baranwal A, Chandra P, Pandey LM. Engineered nanoporous materials mediated heterogeneous catalysts and their implications in biodiesel production. Mater Sci Energy Technol. 2018;1:1121. https://doi.org/10.1016/j.mset.2018.05.002.

127. Azevedo ABA d, Mazzafera P, Mohamed RS, de MSABV, Kieckbusch TG. Extraction of caffeine, chlorogenic acids and lipids from green coffee beans using supercritical carbon dioxide and co-solvents. Brazilian J Chem Eng. 2008;25:543-52. https://doi.org/10.1590/S0104-66322008000300012.

128. Hoang D, Bensaid S, Saracco G. Supercritical fluid technology in biodiesel production. Green Process Synth. 2013;2. https://doi.org/10.1515/gps-20130046.

129. Jokić S, Svilović S, Zeković Z, Vidović S, Velić D. Solubility and kinetics of soybean oil and fatty acids in supercritical CO2. Eur J Lipid Sci Technol. 2011;113:644-51. https://doi.org/10.1002/ejlt.201000403.
130. Abrahamsson V, Rodriguez-Meizoso I, Turner C. Supercritical fluid extraction of lipids from linseed with on-line evaporative light scattering detection. Anal Chim Acta. 2015;853:320-7. https://doi.org/10.1016/j.aca.2014.09.052.

131. Kim J-Y, Oh S, Hwang H, Cho T, Choi I-G, Choi JW. Effects of various reaction parameters on solvolytical depolymerization of lignin in sub- and supercritical ethanol. Chemosphere. 2013;93:1755-64. https://doi.org/10. 1016/j.chemosphere.2013.06.003.

132. Sánchez-Camargo AP, Martinez-Correa HA, Paviani LC, Cabral FA. Supercritical $\mathrm{CO} 2$ extraction of lipids and astaxanthin from Brazilian redspotted shrimp waste (Farfantepenaeus paulensis). J Supercrit Fluids. 2011;56:164-73. https://doi.org/10.1016/j.supflu.2010.12.009.

133. Wang $Y$, Wang $H$, Lin $H$, Zheng $Y$, Zhao J, Pelletier A, et al. Effects of solvents and catalysts in liquefaction of pinewood sawdust for the production of bio-oils. Biomass Bioenergy. 2013;59:158-67. https://doi.org/ 10.1016/j.biombioe.2013.10.022

134. Catchpole O, Tallon S, Dyer P, Montanes F, Moreno T, Vagi E, et al. Integrated supercritical fluid extraction and bioprocessing. Am J Biochem Biotechnol. 2012;8:263-87. https://doi.org/10.3844/ajbbsp.2012.263.287.

135. Farine DR, O'Connell DA, John Raison R, May BM, O'Connor MH, Crawford $D F$, et al. An assessment of biomass for bioelectricity and biofuel, and for greenhouse gas emission reduction in Australia. GCB Bioenergy. 2012;4:14875. https://doi.org/10.1111/j.1757-1707.2011.01115.x.

136. White EM, Latta G, Alig RJ, Skog KE, Adams DM. Biomass production from the U.S. forest and agriculture sectors in support of a renewable electricity standard. Energy Policy. 2013;58:64-74. https://doi.org/10.1016/j.enpol.2013. 02.029 .

137. Clare A, Gou Y-Q, Barnes A, Shackley S, Smallman TL, Wang W, et al. Should China subsidize cofiring to meet its 2020 bioenergy target? A spatiotechno-economic analysis. GCB Bioenergy. 2016;8:550-60. https://doi.org/10. $1111 /$ gcbb. 12264

138. Jiang Y, van der Werf E, van lerland EC, Keesman KJ. The potential role of waste biomass in the future urban electricity system. Biomass Bioenergy. 2017:107:182-90. https://doi.org/10.1016/j.biombioe.2017.10.001.

139. Brown RC. Thermochemical Processing of Biomass: Conversion into Fuels, Chemicals and Power. Chichester: John Wiley \& Sons, Ltd; 2011. https://doi. org/10.1002/9781119990840.

140. Punia R, Marlar RR, Kumar S, Tyagi SK. Potential of bioelectricity production in India through thermochemical conversion of lignocellulosic biomass. In: Sustainable biofuels development in India. Cham: Springer International Publishing; 2017. p. 189-206. https://doi.org/10.1007/978-3-319-50219-9_8.

141. Ng WPQ, Lam HL, Varbanov PS, Klemeš JJ. Waste-to-energy (WTE) network synthesis for municipal solid waste (MSW). Energy Convers Manag. 2014;85: 866-74. https://doi.org/10.1016/j.enconman.2014.01.004.

142. Tan ST, Ho WS, Hashim H, Lee CT, Taib MR, Ho CS. Energy, economic and environmental (3E) analysis of waste-to-energy (WTE) strategies for municipal solid waste (MSW) management in Malaysia. Energy Convers Manag. 2015;102:111-20. https://doi.org/10.1016/j.enconman.2015.02.010.

143. Ruth LA. Energy from municipal solid waste: a comparison with coal combustion technology. Prog Energy Combust Sci. 1998;24:545-64. https:// doi.org/10.1016/S0360-1285(98)00011-2.

144. He J, Lin B. Assessment of waste incineration power with considerations of subsidies and emissions in China. Energy Policy. 2019;126:190-9. https://doi. org/10.1016/j.enpol.2018.11.025.

Ready to submit your research? Choose BMC and benefit from:

- fast, convenient online submission

- thorough peer review by experienced researchers in your field

- rapid publication on acceptance

- support for research data, including large and complex data types

- gold Open Access which fosters wider collaboration and increased citations

- maximum visibility for your research: over $100 \mathrm{M}$ website views per year

At BMC, research is always in progress.

Learn more biomedcentral.com/submission 